\title{
Effect of preferential transport and coherent denitrification on leaching of nitrate to drainage.
}

\author{
David Nagy ${ }^{1}$, Annette E. Rosenbom ${ }^{2}$, Bo V. Iversen ${ }^{1}$, and Finn Plauborg ${ }^{1}$ \\ ${ }^{1}$ Department of Agroecology, Aarhus University, Blichers Alle 20, Tjele, 8830, Denmark. Tel.: +4552798854 \\ ${ }^{2}$ Department of Geochemistry, Geological Survey of Denmark and Greenland, Oester Voldgade 10, Copenhagen K, 1350, \\ Denmark
}

Correspondence: David Nagy (davidnagy@agro.au.dk)

\begin{abstract}
To protect the quality of the aquatic environment, it is imperative to be able to assess the leaching of nitrate through various hydrogeological settings. Numerical model concepts have been developed in order to describe this leaching and possible routes of nitrogen at field scale, often without being evaluated in regard to their ability to account for dominant preferential transport and coherent denitrification, which is the rule rather than the exception in soils. This study evaluates whether it is possible to describe 10-years of nitrate concentrations, measured in drainage from a tile-drained agricultural clay till field in Denmark, by applying the soil-plant-atmosphere model DAISY, capable of accounting for preferential transport and denitrification. A DAISY model concept, including macropores capable of capturing the water and bromide balance of the field within this specific timeframe, was able to predict the water transport to drainage, dry matter and N-yield of the harvested crops, while it was unable, with the standard default denitrification model, to predict dynamics and quantity of N-loss to drainage. This was caused by a fast saturation of the plow layer, where nitrate seemed to be denitrified almost instantly, and no surplus nitrate remained to be transported to the drainage. To circumvent this and describe the measured N-loss, modification to the water reduction function affecting denitrification was conducted. The denitrification had to be reduced by approximately $50 \%$ from a seasonal average of $75 \mathrm{~kg} \mathrm{~N} \mathrm{ha}^{-1}$ to $35 \mathrm{~kg} \mathrm{~N} \mathrm{ha}^{-1}$ while $48 \%$ to $80 \%$ of the total $\mathrm{N}$-loss to drainage had to be preferentially transported from the plow layer. This study therefore reveals that, by not accounting for preferential transport and coherent denitrification, there is a high risk of underestimating leaching of nitrate to the aquatic environment.
\end{abstract}

Keywords. Preferential transport, Denitrification, Modelling, N-leaching, Drainage

\section{Introduction}

Nitrogen is an essential element of crop growth and development. The input of agricultural nitrogen fertilisers, however, is one of the most substantial causes of non-point source nitrogen pollution of surface water (including drainage) and groundwater, despite the Nitrate Directive (EEC, 1991). One of the most widespread impacts on inland surface water and coastal seawater is eutrophication, which is induced by unnatural enrichment of nitrogen and phosphorus. In order to increase agricultural production from the arable land, artificial subsurface tile drains are widely deployed around Denmark to remove excess water from fields with poor natural drainage. Nevertheless, this agricultural water management measure puts the aquatic environment at 
risk since it facilitates rapid nitrogen transport pathways to the aquatic environment, with limited possibilities for the reduction of nitrate (Ernstsen et al., 2015) followed by eutrophication (Blann et al., 2009). Bergstrom (1995) argued that nitrate would be transported evenly through the matrix media and probably not via preferential flow pathways. In contrast, Larsson and Jarvis (1999) showed the importance of macropore flow in regard to nitrate transport in structured soils. Mohanty et al. (1998) found water flow better described by using bimodal unsaturated hydraulic functions accounting for preferential flow of water, rather than with the commonly used unimodal hydraulic functions. Recently, Cheng et al. (2014) have shown that the leaching of nitrate from an undisturbed soil column of loam was, on average, 2.31 times faster than from a packed soil column. Besides the contamination threat to the aquatic environment, agricultural fertilisation practices pose a risk as one of the accelerators of global warming, since they are a source of nitrous oxide $\left(\mathrm{N}_{2} \mathrm{O}\right)$ emission. Hofstra and Bouwman (2005) concluded, by statistical modelling including studies with 336 denitrification measurements in contrasting crop management systems and landscapes, that the possible magnitude of gaseous $\mathrm{N}$ loss was around $10 \mathrm{~kg} \mathrm{Nha}^{-1} \mathrm{yr}^{-1}$ from a well-drained field with an uncertainty of 2-46 $\mathrm{kg} \mathrm{Nha}^{-1} \mathrm{yr}^{-1}$. The authors classified the results based on drainage conditions, such as well-drained and poorly drained, with a contribution of 13 and $22 \mathrm{~kg} \mathrm{~N} \mathrm{ha}^{-1}$, respectively. According to Knudsen et al. (2000), in Denmark, the general "rule of thumb" for sandy clay loam and clay loam is a loss of $20-40 \mathrm{~kg} \mathrm{~N} \mathrm{ha}^{-1} \mathrm{yr}^{-1}$ due to denitrification. Besides nitrogen being a pollution factor, nitrogen is one of the most limiting nutrients for vegetation, which regulates crop productivity in the agricultural ecosystem. The proportion of various nitrogen compounds in the system depends both on the form and the amount of the input of nitrogen (organic or inorganic), but also on transformations in the soil. Although inorganic nitrogen is responsible for both plant production and facilitation of eutrophication, the labile $\mathrm{N}$ compounds account for less than 5\% of the total nitrogen in soil (Brady et al., 2008; Jarvis et al., 1996). Nitrogen is present in organic form as plant residues, but since it is not soluble in water, plants have limited access to this storage. Microorganisms (bacteria and fungi) convert the organic nitrogen into ammonium and nitrate (mineralisation), and this inorganic nitrogen can be mobilised by the root system of plants. The excess available inorganic nitrogen is either transported to surface waters by subsurface tile drain systems or the groundwater, if it is not immobilised or denitrified (Reddy and Ronald, 2008). Today, models applied to assess the water and solute transport include discrete representation of soil layers which, with their hydraulic, chemical and biological properties, drive the organic and inorganic compounds through the simulated soil profile (Manzoni and Porporato, 2009). Such models are often one-dimensional and apply Richard's equation (Richards, 1931) paired with the advection-dispersion equation, and depict the subsurface drain transport with the widely used Hooghoudt equation (Hooghoudt, 1940). Besides the equilibrium water and solute transport, several of these models have included preferential pathways in order to simulate the rapid transport throughout the soil media (Simunek et al., 2003). The ability of these models to describe preferential transport and coherent denitrification in relation to leaching of nitrate has however seldom been evaluated in detail, which is imperative in order to protect the aquatic environment against nitrate pollution. The objective of this study was to evaluate, by using one-dimensional physically-based root zone model DAISY (Hansen, 2002), the effect of preferential transport and denitrification on leaching of nitrate to drainage during a 10-years period as measured for an agricultural clay till field included in the Danish Pesticide Leaching Assessment Programme (PLAP; Lindhardt et al. (2001); web address: http://pesticidvarsling.dk). This was conducted by (a) testing the performance of the preferential flow and transport model concept developed by Nagy et al. (2019) for this 
specific field, in describing the measured loss of nitrate to drainage, and (b) improving this model performance by optimising

the concept regarding sensitive, hydraulic, crop nitrification and denitrification parameters (Hansen et al., 2012a).

\section{Material and Methods}

\subsection{Long-term field experiment}

The experimental field (1.69 ha) has been included in PLAP and is located in Silstrup (56 ${ }^{\circ} 55^{\prime} 56$ "N $8{ }^{\circ} 38^{\prime} 44$ "E) in the North West of Denmark (Lindhardt et al., 2001) (Fig. 1). The field was set up in 1999, with the knowledge that since 1942 the field had been used for agricultural purposes and was artificially drained in 1966 with a systematic and uniform layout of the drain pipe system. The field was farmed from 1983 without the use of plot experiments and, since the monitoring started in 1999, the field has been cultivated with crops in a rotation following Danish standard agronomic procedures concerning soil tillage, fertilisation and spraying with pesticides. The field and the surrounding area are dominated by Weichselian glacial clay till deposits in mixture with thin meltwater sand lenses. The field is heavily fractured and contains a high density of macropores. In the top $1 \mathrm{~m}$, traces of agricultural processes are highly visible, dominated by bioturbation and desiccation cracks, and the macropore density was approximated to 400 pores $\mathrm{m}^{-2}$ (Lindhardt et al., 2001) with diameters of 2-5 mm, utilising the methodology from Klint and Gravesen (1999). The most common horizon subdivision is between the topsoil, or plow layer ( $A_{p}$ horizon), and subsoil (B horizon) with average depths of $31 \mathrm{~cm}$ and $140 \mathrm{~cm}$, respectively. The textural evaluation showed a plow layer with $18-25 \%$ clay and an even more varying clay content within the underlying soil of up to $43 \%$. The loss of pesticides has from the start of the monitoring program been followed by flow proportional sampling of water from the drainage system and grab samples of water from deep groundwater wells, installed at the border of the field. In addition to pesticide leaching assessed from the water samples, nitrate concentration in the same water samples have also been measured. Further details on the monitoring program are given by Lindhardt et al. (2001). In the present study, Silstrup data is included from the period 2000-2010. Silstrup has an average yearly precipitation of $838 \mathrm{~mm}$. The groundwater table is located relatively deep for the duration of the dry seasons with a depth of $2-4 \mathrm{~m}$, whereas during the wet season it varies between $0.5-1.5 \mathrm{~m}$. On average, the drainage was occurring 168 days per year with a mean magnitude of $0.5 \mathrm{~mm} \mathrm{~d}^{-1}$ corresponding to $8.45 \mathrm{~m}^{3} \mathrm{~d}^{-1}$ from the whole field. Most of the drainage occurred during the wet season (late autumn and winter), although occasional sudden preferentially induced flow was observed during the spring and summer period. Further hydrological details can be found in Nagy et al. (2019) and Lindhardt et al. (2001).

Management and measurements: From 2000 through 2010, crops of spring barley (SB) and winter wheat (WW) were grown in rotation with winter rape (WR), fodder beets (FB), pea (P), and maize (M) (Fig. 2). No catch crop has been cultivated. Every single year, the total amount of $\mathrm{N}$ fertilisers applied was adjusted to accommodate the selected crop, considering the nutritional effects of the previous crops in rotation. On average for 2000-2010, the annual $\mathrm{N}$-application was $197 \mathrm{~kg} \mathrm{~N} \mathrm{ha}^{-1} \mathrm{yr}^{-1}$. The climate data was recorded from 29 April 2000 until 31 December 2010 on an hourly basis. The data include wind speed [ms ${ }^{-1}$ ], 
global radiation $\left[\mathrm{W} \mathrm{m}^{-2}\right]$, air temperature $\left[{ }^{\circ} \mathrm{C}\right]$ and vapour pressure $[\mathrm{Pa}]$ to be able to determine the evaporative demand utilising the Penman-Monteith Reference Evaporation equation (Allen et al., 1998). The wind speed measurements at 10 meters height were scaled to 2 meters, assuming a logarithmic wind profile and neutral atmosphere (Allen et al., 1998). Hourly precipitation $[\mathrm{mm}]$ was sampled with a tipping bucket gauge (Lambrecht meteo $\mathrm{GmbH}$ ) at the upper North East end of the field (Lindhardt et al., 2001; Nagy et al., 2019). At the tile drain outlet, hourly drainage discharge was measured using the Thompson weir method (Lindhardt et al., 2001). ISCO samplers (Teledyne ISCO, Lincoln, NE, USA) had been utilised to get samples of drainage water. Drainage water was sampled time proportionally (hourly) until 2004 and thereafter sampled proportional with sub-samples collected for every $3000 \mathrm{~L}$ of drainage flow during the winter months (September-May) and $1500 \mathrm{~L}$ during the summer season (June-August). Each week, all the collected sub-samples were pooled, and a sample was analyzed for nitrate, in the laboratory (Ernstsen et al., 2015). The soil water was sampled with PRENART SUPER QUARTZ suction cups (Prenart, DK)) consisting of porous Polytetrafluoroethylene (PTFE) mixed with quartz. Four suction cups were installed at a depth of 1 $\mathrm{m}$ and four at a depths of $2 \mathrm{~m}$ at the edge of the field (Lindhardt et al., 2001). The sampling bottles are 1- or 2-liter glass bottles, and samples were taken every 7 days. N-concentration and transport: In the period 2000-2010, the nitrate-N concentrations in drainage at Silstrup varied between $0.5-34 \mathrm{mg} \mathrm{N} \mathrm{L}^{-1}$ and, for 20 percent of the time, exceeded the European limit for drinking water (Fig. 2). Slightly elevated nitrate-N concentrations were measured during M2002 (15.47 $\mathrm{mg} \mathrm{N} \mathrm{L}^{-1}$ ), P2003 (13.96 $\mathrm{mg} \mathrm{N} \mathrm{L}{ }^{-1}$ ), WW2006/2007 (12.68 $\mathrm{mg} \mathrm{N} \mathrm{L}^{-1}$ ) and in extreme WW2004/2005 (22.10 $\left.\mathrm{mg} \mathrm{N} \mathrm{L}^{-1}\right)$, FB2008 (34.29 $\mathrm{mg} \mathrm{N} \mathrm{L}^{-1}$ ) was two and three times more than the allowed EU limit for drinking water supply (11.3 $\left.\mathrm{mg} \mathrm{N} \mathrm{L}^{-1}\right)$. Most of the $\mathrm{N}$ leaching occurred throughout the fall- and wintertime, and generally, the daily fluxes were below $1 \mathrm{~kg} \mathrm{Nha}^{-1} \mathrm{~d}^{-1}$. For a short period of time, the concentration hit the range of $1-2 \mathrm{~kg} \mathrm{Nha}^{-1} \mathrm{~d}^{-1}$ and has hardly ever been above $2 \mathrm{~kg} \mathrm{Nha}^{-1} \mathrm{~d}^{-1}$ (Fig. 2). The yearly drainage transport of nitrate- $\mathrm{N}$ coming from the field was between $3-23 \mathrm{~kg} \mathrm{~N} \mathrm{ha}^{-1} \mathrm{yr}^{-1}$, corresponding to $1-16 \%$ of the annually applied $\mathrm{N}$ fertilisers (Fig. 2). Even though $\mathrm{N}$ was applied every year at nearly the same plant development stages, no immediate effects on nitrate- $\mathrm{N}$ concentrations in the drainage were observed. This applied to both mineral and organic $\mathrm{N}$ fertilisers (Ernstsen et al., 2015). Figure 2 presents the water and $\mathrm{NO}_{3}-\mathrm{N}$ leaching accumulated seasonally. One season ran from April $1^{\text {st }}$ of the given year until March $31^{\text {st }}$ of the next year to represent the significant crop growing and $\mathrm{N}$ fertilisation season. This seasonal approach is an alteration from the standard use of the hydrological year, as United States Geological Survey (USGS) defines it, the period between October $1^{\text {st }}$ of one year and September $30^{\text {th }}$ of the following year (U.S.G.S, 2016).

[Figure 2 is about here]

\subsection{The DAISY-model}

DAISY is a one dimensional physically-based root zone model, being able to model water balance, carbon and nitrogen turnover, solute balance, heat balance and crop production based on input of climate data, soil texture, and various management strategies (Hansen, 2002). The water balance includes surface and subsurface matrix and preferential flow processes, as well as plant uptake and flow to tile drains. It puts great emphases on nitrogen balance and modelling of processes in the nitrogen 
cycle, mineralisation-immobilisation, nitrification, and denitrification. Further, it simulates uptake and leaching of ammonium and nitrate to drains and groundwater (Hansen et al., 2012a).

Soil hydraulics: DAISY uses the Richards equation to solve the one-dimensional water transport in the matrix.

$\frac{\delta \theta}{\delta t}=\frac{\delta}{\delta z}\left[K \frac{\delta \psi}{\delta z}\right]+\frac{\delta K}{\delta z}-S$

,where $\theta\left[\mathrm{VV}^{-1}\right]$ is the volumetric water content in the soil, $\psi[\mathrm{L}]$ is the soil water pressure potential, $K\left[\mathrm{LT}^{-1}\right]$ is the hydraulic conductivity of the soil and $\mathrm{S}$ is a sink term, which represents the loss to the drain, macropore or plant water uptake. In order to solve the Richards equation, in this study, the van Genuchten (vG) soil water retention model was used (Van Genuchten, 1980).

$\theta=\left\{\begin{array}{cc}\theta_{r}+\frac{\theta_{s}-\theta_{s}}{\left[1+|\alpha \psi|^{n}\right]^{m}} & ; h<0 \\ \theta_{s} & ; h>0\end{array}\right.$

, where $\alpha, n$ and $m$ are empirical shape parameters, and $\theta_{s}$ and $\theta_{r}$ are the saturated and the residual water content respectively of the given soil. In this study, the van Genuchten model is coupled with the Mualem hydraulic conductivity theory (Mualem, 1976) (vGM), where $m$ is achieved as $m=1-n^{-1}$. The Mualem hydraulic conductivity is expressed as

$K=K_{\text {sat }} S_{e}^{l}\left[1-\left(1-S_{e}^{m^{-1}}\right)^{m}\right]^{2}$

, where $K_{\text {sat }}$ is the hydraulic conductivity at saturation, $S_{e}$ is the effective saturation, which is calculated as, $S_{e}=\frac{\theta-\theta_{r}}{\theta_{s}-\theta_{r}}$ and $l$ is the shape form, which represents the pore connectivity.

The fast flow domain in DAISY is described by a macropore module designed by Mollerup (2010) and tested in technical reports, prepared for and published by the Danish Environmental Protection Agency (Hansen et al., 2010a, b, 2012b). The macropore is a vertically oriented feature in the DAISY model, characterised by physical properties such as length, diameter $(d)$ and density $(\rho)$. The macropore flow is initiated when the matrix pressure exceeds a specific pressure potential called $\psi_{\text {init }}$. If this pressure potential is exceeded, the macropore domain activates and water starts to fill up the macropore. When the pressure potential drops below a level called $\psi_{\text {term }}$, the macropore flow is terminated. In a specific case, when a macropore is filled with water, it can be transferred back to the soil matrix at a certain point. It is initiated when the pressure difference between the macropore and the matrix exceeds a minimum pressure barrier $\psi_{\text {barrier }}$. All pressure parameters are common for all macropore classes. Macropores can be drain ended and matrix ended macropore, where the drain ended macropore has no water build up, because when the water enters into the macropore, it is instantaneously transported to the drain. In contrast, in the matrix macropores, the water has the availability to build up and be transported back to the matrix later, as discussed above. More details of the mathematical and physical description of the macropore domain can be found in Mollerup (2010). Soil N pools: Nitrogen (N) is present in two different fractions in the soil as organic or inorganic forms. These two fractions are in a constant exchange with each other, through mineralisation and immobilisation. According to Jarvis et al. (1996), inorganic $\mathrm{N}$ represents approximately $5 \%$ of the total soil $\mathrm{N}$, although it may change after fertilisation for a short period. Hence, organic 
$\mathrm{N}$, which occurs in many forms, including proteins, urea, amino and nucleic acids and nucleotides is by far the largest $\mathrm{N}$ fraction of the soil.

Although the microbial state of $\mathrm{N}$ may cover only 3-5\%, most of the transformation processes (mineralisation, immobilisation, and denitrification) are mediated by the microbial community. In DAISY, soil N is divided into six different pools (Fig. 3), and some $\mathrm{N}$ is in an inert pool (not shown in Fig. 3). The pools are separated into two distinct groups, pools with slow turnover rate (denoted 1), and pools with higher turnover rate (denoted 2). Thereby the soil organic matter pool 1 (SOM1) mainly contains chemically stabilised compounds which are relatively resistant to biological degradation. The other organic matter pool (SOM2) is physically stabilised and more labile, although temporarily resistant to biodegradation due to sorption to soil colloids. Added organic matter refers to manure, crop residue or green manure and is typically divided into AOM1 - cell wall material and AOM2 cell extractable substances. The main driver of the $\mathrm{C} / \mathrm{N}$ turnover is the soil microbial biomass (SMB), which controls the turnover processes of the dissolved organic matter, even though it only represents a small quantity of the total organic matter (Hansen, 2002). Mineralisation-immobilisation turnover: Net N mineralisation or net $\mathrm{N}$ immobilisation is determined by the microbial activity and the overall $\mathrm{N}$ balance. If the content of $\mathrm{N}$ in the assimilated organic substance is higher than that required by the biomass for growth, ammonium is excreted to the soil solution. On the other hand, if the content of $\mathrm{N}$ in the assimilated organic substance is lower than that required by the biomass for growth, ammonium or nitrate is assimilated from the soil solution and transformed into nitrogenous organic compounds (Hansen, 2002). The measure used in DAISY for the available organic substrate is the content of carbon in the organic matter. Hence, the simulation of net mineralisation of $\mathrm{N}$ is based on the simulation of the turnover rate of soil organic carbon. The potential decomposition rate of organic carbon in various pools in the soil is described by first-order kinetics, but is affected by the abiotic factors (soil water content, soil temperature, $\mathrm{pH}$ (5 to 8), oxygen pressure) and availability of inorganic $\mathrm{N}$. The potential $\mathrm{N}$ mineralisation rate is strongly related to the carbon turnover, as every sub-pool has a $\mathrm{C}: \mathrm{N}$ ratio and the decomposition of carbon leads to mineralisation of $\mathrm{N}$ carbon according to this ratio. Hence, the potential background $\mathrm{N}$ mineralisation from dead native organic matter in the soil is highly dependent on the distribution of the dead native soil organic matter between SOM1 and SOM2, which in turn is strongly related. By default, the C:N ratio for SMB1 and SMB2 is assumed to be 6 and 10, respectively, however, it can be specified differently if required. Denitrification: In the present model, denitrification is simulated using a rather simple index type model considering the decomposition of organic matter, volume of anaerobic microsites expressed simply in terms of soil water content, soil temperature, and the concentration of nitrate in soil solution. This is a typical way of using a simplified model for denitrification (Eq. 4), according to Heinen (2006):

$D_{a}=\alpha_{d} f_{N} f_{S} f_{T} f_{p H}$

,where $D_{a}$ is the actual denitrification rate, $\alpha_{d}$ represents the potential but may in different models have different formulation, $f_{N}$ is a dimensionless reduction function for nitrate content in soil or represents the nitrate content in the soil (depending on the exact formulation determined by $\left.\alpha_{d}\right), f_{S}$ is a dimensionless reduction function for water content in the soil, $f_{T}$ is a 
dimensionless reduction function for temperature in the soil, and $f_{p H}$ is a dimensionless reduction function for soil $\mathrm{pH}$. The $\alpha_{d}$ parameter can be considered in two ways, depending on the model concept; either $\alpha_{d}$ represents the potential denitrification rate $D_{p}$ (same units as $D_{a}$ ) or it represents a first-order denitrification coefficient (constant) $k_{d}$. In both cases, $\alpha$ can be a constant parameter or can be related to carbon dynamics. In the DAISY model, the potential denitrification rate (in case of anoxic conditions and sufficient nitrate concentration in the soil solution) is expressed as a linear function of the $\mathrm{CO}_{2}$ evolution rate:

$\xi_{d}^{*}=\alpha_{d}^{*} \xi_{C O_{2}}$

,where $x i_{d}^{*}$ is the potential denitrification rate of the soil, $x i_{C O_{2}}$ is the $\mathrm{CO}_{2}$ evolution rate simulated by the mineralisation - immobilisation - turnover model (MIT-model), and $\alpha_{d}^{*}$ is an empirical constant, which was taken from Lind (1980), who measured the relationship between easily decomposable organic matter and denitrification capacity. The actual denitrification rate is determined either by the actual microbial activity at the anaerobic microsites, or the transport of nitrate to the anaerobic microsites represented by the left and right solution, respectively, in Eq. (6). In the case of ample supply of nitrate, the actual denitrification rate is determined by multiplying the potential denitrification rate by a modifier function. Hence, the actual denitrification can be simulated as:

,where $x i_{d}$ is the actual denitrification, $K_{d}$ is an empirical proportionality factor when denitrification is governed by the microbial activity at the anaerobic microsites and $N_{n} i$ the nitrate concentration in the soil. The maximum transport of nitrate to microsites can be assumed to be relative to the nitrate concentration in the soil ( $N_{n i}=\theta C_{n i}$, where $C_{n i}$ is the concentration in the soil solution, and $\theta$ is the soil water content). In Eq. (6), the modifier function $f_{S}$ is assumed to be a function of the soil water content. Many models use a power reduction function of the form (Grundmann and Rolston, 1987):

$0 \quad ; S<S_{t}$

$\left(\frac{S-S_{t}}{S_{m}-S_{t}}\right)^{w} \quad ; S_{t} \leq S \leq S_{m}$

$$
1 \quad ; S_{m}<S
$$

,where $f_{S}$ is the dimensionless power water reduction function in the range [0,1], $S$ is the dimensionless degree of water saturation or water-filled pore space; $S$ is always in the range [0,1], $S_{m}$ is close to full water saturation above which $f_{S}=1$, $S_{t}$ is a threshold value for $\mathrm{S}$ below which $f_{S}=0, w$ is a curve shape parameter determining the steepness of the curve (Heinen, 2006). The temperature modifier function $f_{T}$ is an Arrhenius like function (Rodrigo et al., 1997) by correlating the exponential rate of biological processes to the increasing temperature. According to Heinen (2006), based on a sensitivity test on Eq.(4), $f_{S}$ is the most sensitive within all modifiers. Therefore, this study is only focusing on the water saturation effect on denitrification in the aspect of calibration Eq.(4). 


\subsection{Initial model concept}

215 Nagy et al. (2019) conceptualised the water and solute transport for the clay till field Silstrup with three different macropore settings and three different horizons (A, B and C). The macropore settings included vertical macropore transport supplying water directly to 1) the drainage pipes, 2) to drainage pipes and the matrix 3) to drainage pipes and the matrix added with fractures, supplying water to the matrix in the saturated zone. The best-calibrated concept with drainage ending macropores (DM1, DM2) and matrix (MM1, MM2, MM3) ended macropores (Fig 4a), yielded indices for the evaluation of measured and simulated drainage, 0.12/0.48 nMAE (normalized Mean Absolute Error) and 0.87/0.82 KGE (Kling -Gupta Efficiency) and for the bromide drainage transport 0.14/0.85 nMAE with 0.85/0.52 KGE. Further details in Nagy et al. (2019) (Fig. 4b, 4c).

[Figure 4 is about here]

\subsection{Objectives included in the automated calibration procedure}

The soil and hydrological parameters are adjusted in order to improve the bromide $\left(\mathrm{Br}^{-}\right)$transport as in the hydrological model by Nagy et al. (2019), which was not calibrated on $\mathrm{Br}^{-}$transport. A better performance of the model could particularly be expected just after the application of $30 \mathrm{~kg} \mathrm{KBr} \mathrm{ha}^{-1}$, corresponding to $20.14 \mathrm{~kg} \mathrm{Br} \mathrm{ha}^{-1}$ (cf. Fig. 9 in Nagy et al. (2019)). Therefore new objectives have been included in the calibration procedure, such as the harvested dry matter yield - DM yield, harvested $\mathrm{N}$ yield $-N$ yield, $\mathrm{N}$ drainage flux dynamics $-N D\left[\mathrm{~kg} \mathrm{~N} \mathrm{ha}^{-1} \mathrm{~h}^{-1}\right]$ and cumulative $\mathrm{N}$ transport $-N C\left[\mathrm{~kg} \mathrm{~N} \mathrm{ha}^{-1} \mathrm{~h}^{-1}\right]$, $\mathrm{Br}^{-}$transport dynamics $-B R D 1\left[\mathrm{~kg} \mathrm{Brha} \mathrm{h}^{-1} \mathrm{~h}^{-1}\right]$ and cumulative transport $-B R C l$ for the whole tracer experiment period

$\left[\mathrm{kg} \mathrm{Br} \mathrm{ha}{ }^{-1} \mathrm{~h}^{-1}\right], \mathrm{Br}^{-}$transport dynamics $\left.-B R D 2 \mathrm{~kg} \mathrm{Br} \mathrm{ha}^{-1} \mathrm{~h}^{-1}\right]$ and cumulative transport $-B R C 2\left[\mathrm{~kg} \mathrm{Br} \mathrm{ha}{ }^{-1} \mathrm{~h}^{-1}\right]$ for the period of initial $\mathrm{Br}^{-}$breakthrough (1 April 2000 - 1 June 2000) and to not compromise the earlier findings from Nagy et al. (2019), the drainage dynamics - $D D\left[\mathrm{mmh}^{-1}\right]$ and cumulative transport - $D C[\mathrm{~mm}]$ including soil water content measurement $\left[\mathrm{cm}^{3} \mathrm{~cm}^{-3}\right.$ ] at depth $25 \mathrm{~cm}-S 25$ and $60 \mathrm{~cm}-S 60$ were included. According to Muleta (2011) and Nagy et al. (2019), the mean absolute error was used for calibration. Since the model was constrained to different objectives with different units, the objectives in Eq.(8) were normalized by means of the corresponding observations in order to aggregate them into one objective function, which is eligible for automated calibration (Criss and Winston, 2008; Nagy et al., 2019).

$n M A E_{\text {season }}^{o b j}=\frac{\frac{1}{N} \sum_{i=1}^{N}\left|\operatorname{sim}_{\text {season }, i}^{o b j}-o b s_{\text {season }, i}^{o b j}\right|}{\text { obs season }_{\text {sobj }}} ; o b j=\{N D, N C, D D, D C, S 25, S 60\}$

,where $\mathrm{N}$ is the number of observations of a given objective within a year and

$\overline{\text { obs seajon }}=\frac{1}{N} \sum_{i=1}^{N} o b s_{\text {season }, i}^{o b j}$

240

$\overline{n M A E^{o b j}}=\frac{1}{K} \sum_{k=1}^{K} n M_{\text {season, } i}{ }^{o b j}$ 
,where $\mathrm{k}$ is the number of calibration years. Due to DM yield and $N$ yield having only one value per season, a seasonal aggregation is not possible. Thus, nMAE was calculated for all seasons and normalized by means of the observations. The same applied to the $\mathrm{Br}^{-}(B R D 1, B R C 1, B R D 2, B R C 2)$ objectives due to the tracer experiment being held for one season in 2000-2001. The multi-objective function calculated for the automated calibration is expressed as:

$n M A E^{\text {final }}=\sum \overline{n M A E^{o b j} ;} \quad o b j=\left\{\begin{array}{c}N \text { yield, DM yield }, N D, N C, \\ B R D 1, B R C 1, B R D 2, B R C 2, \\ D D, D C, S 25, S 60\end{array}\right\}$

For further evaluation purposes nRMSE[\%] (normalized Root Mean Squared Error), normalized on the difference on the minimum-maximum deviation of the observation and KGE (Kling-Gupta efficiency measure were calculated. KGE is presented by Gupta et al. (2009)). Singh et al. (2005) and Hansson and Hokfelt (1975) suggested that if MAE or RMSE of the model is lower than half of the standard deviation (SD) of the measured data, the model may be considered as an adequate representation of the measured data. On the other hand, KGE with a range of $-\infty$ to 1 , if $\mathrm{KGE}$ is above 0.5 , the model can be considered as satisfactory.

\subsection{Parameters}

The hydrological parameters were taken from Nagy et al. (2019) as it is considered to be a reasonable baseline for the calibration (Table 1 and 2). All initial hydraulic parameters represented presented in Table 1, and 2 were given a $\pm 5 \%$ uncertainty boundary range in order to see which parameter would be influential on the "new" objectives.

[Table 1 is about here]

For the fast flow domain, the macropore model of DAISY using the conceptualisation of Nagy et al. (2019) was applied (Table 2).

To be able to evaluate the model behaviour considering the "new" objectives conditions, one has to determine essential input parameters important for calibrating $\mathrm{N}$ loss by crop harvest, nitrate leaching and gaseous $\mathrm{N}_{2}$ loss due to denitrification (Table 3). Only crop parameters influencing dry matter formation were selected, as the data available did not allow a calibration of the $\mathrm{N}$ uptake parameters.

The simple photosynthesis description in DAISY requires a value for maximum assimilation rate $\left(F_{m}\right)$ [ $\left.\mathrm{g} \mathrm{CO}_{2} \mathrm{~m}^{-2} \mathrm{~h}^{-1}\right]$, quantum efficiency $\left(Q_{e f f}\right)\left[\left(\mathrm{g} \mathrm{CO}_{2} \mathrm{~m}^{-2} \mathrm{~h}^{-1}\right)\left(\mathrm{W} \mathrm{m}^{-2}\right)^{-1}\right]$ at low light, and a temperature factor for assimilating production, referred to as a piece-wise linear function (PLF) (Hansen et al., 2012a; Vries, 1989). Also, to get more control over the crop production the conversion efficiency (growth respiration) $(E)\left[\left(\mathrm{g} \mathrm{CH}_{2} \mathrm{O}\right)(\mathrm{g} \mathrm{DM})^{-1}\right]$ (Manevski et al., 2016; Vries, 1989) was taken into the calibration besides the Photosynthetic Active Radiation extinction coefficient $\left(\operatorname{Par}_{\text {ext }}\right)$ and the temperature 
sum at emergence ( $T_{\text {sum }}$, Table 3). Additionally, the crop uptake reflection factor of $\mathrm{Br}^{-}\left(C U R F_{B R}\right.$, (Hansen, 2002)), the SOM fraction ratio of the plow layer $\left(S O M_{\text {ratio }}\right)$ which describes the ratio SOM1:SOM2 has been added as a parameter, as well as parameters from the denitrification module for both fast and slow pools: the anaerobic denitrification constant $\left(\alpha_{d}^{*}\right)$ $\left[\left(\mathrm{g} \mathrm{NO}_{3}-\mathrm{Nh}^{-1}\right)\left(\mathrm{g} \mathrm{CO}_{2}-\mathrm{Ch}^{-1}\right)^{-1}\right]$ and the empirical proportionality factor $\left(K_{d}\right)$ from Eq.(5) and Eq.(6), respectively, and $S_{t}$ and $w$ from Eq.(7) (Table 4).

[Table 4 is about here]

The initial values of the selected crop and denitrification parameters were based partly on the values recommended for DAISY in the model library (https://DAISY.ku.dk/, Hansen et al. (2012a)) and on literature screening. Due to the lack of data on the crop growth, $\mathrm{N}$ uptake, and partitioning during the growth season, no extensive calibration of the crop models was possible.

\subsection{Sensitivity analysis}

The range of crop parameter values is biologically constrained by the diversity of crops and their cultivars. Given the lack of knowledge associated with the range of the variability that is genetic for most of the crop model parameters, uniform distribution for each parameter was assumed with $\pm 20 \%$ uncertainty bound except $\operatorname{Par}_{\text {ext }}$ where the bounds were set $\pm 50 \%$. All denitrification related parameters were given $\pm 10 \%$ uncertainty bounds except for the water reduction function, the ranges for which were taken from Heinen (2006). The SOM fraction ratio varied within from 0.43 to 2.33 , which indicate fractions of SOM1:SOM2 as 0.3:0.7 to 0.7:0.3 and $C U R F_{B R}$ could vary from 0 to 1 , where 1 means no crop uptake. Key parameters directly related to crop development, leaf photosynthesis, and net mineralisation of plow layer as one of the input source of denitrification, were tested for sensitivity by the Morris sensitivity screening (Campolongo et al., 2007; Morris, 1991; Nagy et al., 2019) in order to help in finding sensitive parameters that have the most influence on objectives presented in section 2.4. The results of the sensitivity screening were turned into the Morris distance( $\epsilon$ ) (Ciric et al., 2012; Jabloun, 2015), which represents the Euclidean distance of the parameter from $(0,0)$ on the $\mu^{*}-\sigma$ coordinate system (Campolongo et al., 2007). The decision on sensitivity threshold was made by K-Means Clustering (Jain and Dubes, 1988). For each objective, the parameters were clustered into 3 groups (Low, Medium, High) by its $\epsilon$.

\subsection{Calibration methodology}

The overall objective function was based similar to the mathematical formulation, which was used in Nagy et al. (2019), by calculating the normalized Mean Absolute Error of each objective described in section 2.6 annually for the period of 20002007. In order to stabilise the $\mathrm{N}$ dynamics, 4 years were run prior to 2000 as a warm-up period. The calibration of the model was done by differential evolution (DEoptim, Ardia D. (2016)) in conjunction of RDAISY R package [under development] and RDAISY toolbox (Jabloun et al., 2014). 


\section{Results and discussion}

\subsection{Sensitivity screening results}

Overall six soil matrix parameters per horizon (A, B, C), the SOM ratio for the A horizon plus two horizon depth parameters, two macropore parameters per macropore type (DM1, DM2, MM1, MM2, MM3), two soil water pressure parameters for macropores, four denitrification parameter per pool (slow/fast) and one $\mathrm{Br}^{-}$parameter called soil-hydraulic parameters (SH) and eight parameters per crop as crop parameters (CP) were tested for sensitivity. All parameters were selected as a sensitive parameter, which belongs to group High, in at least one of the objectives (Fig. 5). However, to put more emphasis on the $N D$ and $N C$ objectives, parameters which belonged to sensitivity group Medium of $N D$ and $N C$ were also selected as sensitive and added to the calibration parameters (Fig. 5). All selected parameters which were involved in sensitivity analysis against 12 objective functions were listed with their associated sensitivity group (Fig. 5). Parameters with black letters are the selected sensitive parameters and with gray letters the non-sensitive. Even though a large number of parameters have been evaluated, only $16 \mathrm{CP}$ and $21 \mathrm{SH}$ parameters showed to be sensitive to the objective functions. All the sensitive CP parameters were, as expected, sensitive to $N$ yield, since all crop parameters are related to crop growth and therefore directly affecting the crop $\mathrm{N}$ uptake.

[Figure 5 is about here]

SH parameters showed more diversity regarding sensitivity towards the objectives. This is in contrast to CP parameters, which mainly were sensitive towards $N$ yield and DM yield. There was no single parameter which showed to be sensitive for all objectives. Only one SH parameter, $S_{t}$, affecting the denitrification reduction factor, had an effect on DM yield (Fig. 5). As also seen in Figure 5, no matrix and macropore SH parameter was sensitive in the objective function for DM yield. Therefore, it can be inferred that the crops were not affected by water stress. Furthermore, no macropore SH parameters were sensitive in the objective functions for DM yield and $N$ yield. Even though the uncertainty bound was only $\pm 5 \%$ for the SH macropore parameters, the $\mathrm{N}$ dynamics, and quantity objectives $(N D, N C)$ showed no sensitivity on the preferential transport. This could mean that the $\mathrm{N}$ transport is not affected dramatically by the preferential transport change, although earlier studies showed macropore influences on water and solute movement (Larsson and Jarvis, 1999; Nagy et al., 2019). However, the denitrification parameter, $S_{t}$, showed one of the highest impacts on $N C$ objective, which represents the N quantity in the drainage water. This high sensitivity might be related to the fact that the denitrification is limiting the amount of $\mathrm{NO}_{3}-\mathrm{N}$, which would be transported by hydrological means.

\subsection{Model calibration}

Through the calibration procedure, it was found that the ND and $N C$ objectives were not responsive to the initially selected crop and hydraulic parameters. Since the $\mathrm{Br}^{-}$transport in the drainage simulated by the baseline model showed agreement to the accumulated measured transport, with underprediction of initial breakthrough after spraying of $\mathrm{KBr}$ (Fig. 4). The simulated $\mathrm{Br}^{-}$uptake by FB was verified by Nagy et al. (2019); thus, the solute leaching to the groundwater seems to approximate well 
to reality. If all these conditions are probable, $\mathrm{NO}_{3}-\mathrm{N}$ can be only limited by gaseous loss; therefore, the denitrification model parameters had to be involved in the sensitivity and calibration process.

[Table 5 is about here]

As mentioned above, the sensitivity and the calibration process were done by minimising the mean nMAE performance measures. For a broader evaluation, KGE and nRMSE[\%] are also presented in Table 5. The calibrated objective results show that significant improvements were achieved in all solute transport accounts (BRD1, BRC1, BRD2, BRC2, ND, NC), without compromising any of the water balance objectives $(D D, D C, S 25, S 60)$. By observing the $N$ yield and $N C$ objectives, one can see that $\mathrm{N}$ transport $N D$ was improved without creating nitrogen stress in the crop. $\mathrm{Br}^{-}$transport improved during the tracer experiment period, as the model was able to provide a reasonable fit for the initial breakthrough (BRD2, and $B R C 2$, Table 5, Fig. 6). Table 6 shows the calibrated parameters and their initial value. There was no substantial change within the SH parameters. The $S O M_{\text {ratio }}$ increased, the SOM1 became 0.63 , and SOM2 became 0.37 from the initial 0.5 .

[Table 6 is about here]

The most significant changes appeared for parameters directly related to the denitrification reduction function $\left(S_{t, f a s t}, w_{f a s t}\right.$, $S_{t, \text { slow }}, w_{\text {slow }}$; Table 6), which may indicate that the default reduction function in DAISY overestimated this type of N loss.

\subsection{Water and bromide transport}

[Figure 6 is about here]

The improvement of $\mathrm{Br}^{-}$transport yielded a larger initial breakthrough (Fig. 6) without compromising the water balance. The $\mathrm{Br}^{-}$transport mainly responded to the change of the matrix pore distribution (van Genuchten " $\mathrm{n}$ ") in the horizon of A and B ( $n_{A}$ and $n_{B}$, Fig. 5), although it could be the result of the interaction of multiple parameters.

[Figure 7 is about here]

The crop uptake reflection factor increased only slightly from 0 to $0.34 \%$. The FB dry matter yield decreased from 14.5 $\mathrm{Mg} \mathrm{DM} \mathrm{ha}{ }^{-1}$ to $13.7 \mathrm{Mg} \mathrm{DM} \mathrm{ha}^{-1}$. However, the $\mathrm{Br}^{-}$uptake in fodder beet increased from $11.6 \mathrm{~kg} \mathrm{Br} \mathrm{ha}^{-1}$ to $12.1 \mathrm{~kg} \mathrm{Br} \mathrm{ha}{ }^{-1}$, which resulted in a $2 \%\left(0.5 \mathrm{~kg} \mathrm{Br} \mathrm{ha}^{-1}\right)$ higher $\mathrm{Br}^{-}$uptake of the initially sprayed $20.1 \mathrm{~kg} \mathrm{Br} \mathrm{ha}^{-1}$. The $0.5 \mathrm{~kg} \mathrm{Br} \mathrm{ha}{ }^{-1}$ pro- $^{-}$ portionately removed from all $\mathrm{Br}^{-}$leaching routes and macropore leaching remained at the same magnitude. Therefore, it can be inferred that the matrix and macropore interchange did not change significantly (Fig. 7).

\subsection{Nitrogen transport and harvest}

Considering the calibrated $\mathrm{Br}^{-}$transport, the overall leached quantity of $\mathrm{Br}^{-}$did not change substantially. This contrasted with $\mathrm{N}$ transport, which responded differently to the calibration. The original model captured the $\mathrm{N}$ dynamics, and in one instance the magnitude, of the cumulated transport during the WW2003-2004 season. The application of N fertilisers was not reflected in simultaneous or subsequent increases of $\mathrm{N}$ flux from the field, as well as there being no significant additive effect from crop type identified. 
[Figure 8 is about here]

Figure 8 shows that the denitrification in the original model significantly outweighed the $\mathrm{N}$ loss by drains (measured $\mathrm{NO}_{3}-\mathrm{N}$ ) with one order of magnitude with an average seasonal loss of $75 \mathrm{~kg} \mathrm{~N} \mathrm{ha}^{-1}\left(18-151 \mathrm{~kg} \mathrm{~N} \mathrm{ha}^{-1}\right)$, due to denitrification from slow and fast pools combined. Hence, it seems that denitrification limited the amount of $\mathrm{N}$ transported to the drainage. Nagy et al. (2019) discovered that most of the water build up was above the plow pan in the A horizon. This could lead to this rapid denitrification, according to Eq.(4) to Eq.(7) where one of the modifying components is the $f_{S}$ water factor. In DAISY, $f_{S}$ had been set as default in order to increase linearly from 0 to 1 as a function of S from 0.7 to 1.0 (Hansen, 2002) (Fig. 9). This linearity does not fit the real condition for denitrification, since the stagnation of the water above the plow pan, as it presented in Nagy et al. (2019), should allow the $\mathrm{N}$ almost instantaneously to denitrify. In the calibrated model, $f_{S}$ dynamics based on Eq.(7) have been changed, which resulted in a steeper reduction of the denitrification (Fig. 9). By allowing the separation of the reduction factor for both the fast and the slow pool, the calibration of the model showed that the denitrification from the fast pool was shrunk to the range approx. from 0.9 to 1.0 relative saturation, while the slow pool remained like the default version of DAISY.

[Figure 9 is about here]

The modified $f_{S}$ showed a high impact on the $\mathrm{N}$ leaching, as the reduced denitrification enabled the model to depict the amount of $\mathrm{N}$ transported to the drain. The main increase appeared in the directly connected macropore flow (DM1 flow, cf. Fig. 4.), which mainly drained water from the A horizon. Since the mineralisation process is faster from the fast pool, the available mineral $\mathrm{N}$ was not readily reduced to gaseous $\mathrm{N}$, but instead transported through preferential pores to the drain. The average seasonal denitrification was reduced to $34 \mathrm{~kg} \mathrm{~N} \mathrm{ha}^{-1}\left(9-62 \mathrm{~kg} \mathrm{~N} \mathrm{ha}^{-1}\right)$, a reduction of more than $55 \%$ percent, which instead was made available for crop uptake, flow to the drainage system or the groundwater. The harvested DM and $\mathrm{N}$ did not show significant differences before and after calibration (Fig. 10). Some crop N and DM yield were closer to the measured values after calibration, but although the surplus of $\mathrm{N}$ was increased by the lowered denitrification, this additional $\mathrm{N}$ was not taken up by the crops. Overall, the objectives of DM yield and $N$ yield were improved with the modified crop parameters (cf. Table 6 and Fig. 10). However, none of the models showed a satisfactory match for $\mathrm{N}$ yield. For both the original and the calibrated model, the comparison between measured and simulated $\mathrm{N}$ yield showed differences of more than $10 \mathrm{~kg} \mathrm{~N}$ ha $^{-1}$ and even 20 $\mathrm{kg} \mathrm{N} \mathrm{ha}^{-1}$ for maize in 2002 and winter wheat in 2007. As earlier stated, a calibration of the $\mathrm{N}$ uptake parameters in the crop models governing the $\mathrm{N}$ uptake during the season was not possible, as the data available did not contain samples of biomass and hence $\mathrm{N}$ uptake during the season.

[Figure 10 is about here]

\subsection{Evaluation of the model performance related to nitrogen loss routes}

The period 2007-2008 involving crop rotations of WW2006-2007 and FB2008 was selected to test the performance of the calibrated model in simulating $\mathrm{N}$ transport to drains and loss to groundwater. Season 2009-2010 was excluded from the evaluation since a few water balance discrepancies were discovered. Some of the precipitation input and drainage transport was not 
aligned or missing, so the measured values could not be reliable. Besides data from this calibration independent evaluation period, data series of $\mathrm{N}$ concentration sampled with suction cups at depths of $1 \mathrm{~m}$ and $2 \mathrm{~m}$ for the period from 2000 to 2010 were used to validate the $\mathrm{N}$ transport to both drainage and groundwater.

\subsection{Nitrogen transport in drainage water and deep leaching to groundwater}

The $\mathrm{N}$ flux was remarkably improved according to all performance measures for the period 2007-2008 (Fig. 11). For the original modelling of the two cropping seasons, the average KGE was below zero, indicating that the observed mean $\mathrm{N}$ flux was better predicted than the simulated one. In contrast, the calibrated model gave satisfactory results with KGE of 0.56 and 0.5 for the objective $N D$ and $N C$, respectively, which in the case of solute transport modelling is an excellent result (Hansson and Hokfelt, 1975; Singh et al., 2005). Although the comparison for the drainage season 2008-2009 was improved even after calibration, less $\mathrm{N}$ loss to the drain system was simulated. The difference in simulated and measured $\mathrm{N}$ uptake in FB could not explain this difference.

[Figure 11 is about here]

The loss due to denitrification has changed similarly for the calibration period 2000-2007 from seasonal 75 to $35 \mathrm{~kg} \mathrm{~N} \mathrm{ha}^{-1}$, which is approximately a $50 \%$ percent reduction in total. In season 2007-2008, after the WW2006-2007 crop, a satisfactory match between measured and simulated accumulated $\mathrm{N}$ losses to the drainage could exclusively be explained from the reduced denitrification loss (Fig. 11). As mentioned above, soil $\mathrm{N}$ concentration in soil water sampled with suction cups was used for validation purposes. The soil water $\mathrm{N}$ concentration had similar behaviour before and after the calibration, except the dynamics were better matched after calibration (Fig. 12). During the WW2003-2004 crop drainage period, the calibrated model was able to depict the $25 \mathrm{mg} \mathrm{N} \mathrm{L}^{-1}$ measured peak as well as the fluctuations from 2002 to 2004 . However, both models underestimated the N concentration substantially in the period after WW followed by FB 2007-2008. Again, these differences could not be explained by an overestimated high $\mathrm{N}$ uptake (cf. Fig. 10). Although the drainage input of $\mathrm{N}$ massively increased due to the change in denitrification, the simulated $\mathrm{N}$ concentration only improved nRMSE[\%] 5\%-point for the whole period, which is equal to $1 \mathrm{mg} \mathrm{N} \mathrm{L}^{-1}$. Visual and mathematical inspection of the $\mathrm{N}$ concentration show, of course, a decent improvement on the soil $\mathrm{N}$ dynamics, but with this pronounced change in denitrification, the expected rise could be expected to be higher, if the more available $\mathrm{N}$ was not transported further down to the lower soil matrix (Fig. 1a) as DM1 and DM2 macropores start either from the surface or from the bottom of the plow layer (A horizon). However, both are conceptually described to transport water and nutrients to the drainage system, and water build up is not allowed in the model. Besides, three other MM type macropores are present in this conceptual system with the possibility to transport water and solute: from surface to the bottom of the plow pan (MM1), from the surface to below the drain level at $150 \mathrm{~cm}$ depth (MM2) and from the bottom of the plow layer to below the drain level at $150 \mathrm{~cm}$ depth (MM3).

[Figure 12 is about here]

The latter two have the capability to transport $\mathrm{N}$ from the surface/plow layer below the drain level, bypassing the entire $\mathrm{B}$ horizon. This limits the transport through the mentioned horizon by matrix flow. The conceptual description of deep macropores 
https://doi.org/10.5194/hess-2019-666

Preprint. Discussion started: 16 January 2020

(c) Author(s) 2020. CC BY 4.0 License.

points out another possible rapid transport route for $\mathrm{N}$ from the plow layer towards the groundwater. By comparing the measured suction cups samples with the simulated concentrations at $2 \mathrm{~m}$ depth, a remarkable $30 \%$-point decrease can be observed in the nRMSE[\%] and 0.3 nMAE performance measure (Fig. 13). Rosenbom et al. (2009) concluded that deep fractures might result in deep leaching of agrochemicals and nutrient. However, these flow phenomena were outside the scope of the present study.

[Figure 13 is about here]

\section{Conclusions}

This study aimed to evaluate, by using one-dimensional physically based root zone model DAISY (Hansen, 2002), the effect of preferential transport and denitrification on leaching of nitrate to drainage during a 10-years period, as measured for an agricultural clay till field included in the Danish Pesticide Leaching Assessment Programme (PLAP; Lindhardt et al. (2001); web address: http://pesticidvarsling.dk). The results reveal a dominant effect on the leaching of nitrate through this clay till field. A large amount of $\mathrm{N}$ (48\% to $80 \%$ of the total N-loss to drainage) was preferentially transported via macropores to drainage, regardless of the application method and concurrent occurrence of precipitation. The current standard denitrification water reduction factor, fs, needed modification with a reduction of approximately $50 \%$ in the denitrification of the field from a seasonal average of $75 \mathrm{~kg} \mathrm{Nha}^{-1}$ to $35 \mathrm{~kg} \mathrm{~N} \mathrm{ha}^{-1}$. The crop model provided acceptable results, and further studies are needed to improve the simulation of $\mathrm{N}$ uptake in crops. Overall, this study delineates the importance of accounting for preferential transport and coherent denitrification in the assessment of the leaching risk of nitrate to the aquatic environment.

Author contributions. David Nagy(DN) carried out the development of the conceptualisation and methodology under the co-supervision of Annette E. Rosenbom(AER) and Bo Vangsø Iversen(BVI) and main supervision of Finn Plauborg(FP). DN developed the model calibration code, performed the simulations and prepared the manuscript with contributions from all co-authors. AER provided the PLAP experiment data of Silstrup, whereas FP provided the corresponding climate data. AER and FP are responsible for the data curation of the experiment. 


\section{References}

Allen, R. G., Pereira, L. S., Raes, D., and Smith, M.: Crop evapotranspiration-guidelines for computing crop water requirements-fao irrigation and drainage paper 56, FAO, Rome, 300, D05 109, 1998.

Ardia D., Mullen K.M., P. B. U. J.: 'Deoptim': An r package for global optimization by differential evolution., http://www.jstatsoft.org/v40/ i06/, 2016.

Bergstrom, L.: Leaching of dichlorprop and nitrate in structured soil, Environ Pollut, 87, 189-95, https://doi.org/10.1016/02697491(94)p2606-a, https://www.ncbi.nlm.nih.gov/pubmed/15091593, 1995.

Blann, K. L., Anderson, J. L., Sands, G. R., and Vondracek, B.: Effects of agricultural drainage on aquatic ecosystems: A review, Critical Reviews in Environmental Science and Technology, 39, 909-1001, https://doi.org/10.1080/10643380801977966, <GotoISI>://WOS: $000272596000001,2009$.

Brady, N., Weil, R., Brady, N., and Weil, R.: Soil colloids: Seat of soil chemical and physical acidity, 2008.

Campolongo, F., Cariboni, J., and Saltelli, A.: An effective screening design for sensitivity analysis of large models, Environmental Modelling \& Software, 22, 1509-1518, https://doi.org/10.1016/j.envsoft.2006.10.004, <GotoISI>://WOS:000247403800013, 2007.

Cheng, J. H., Zhang, H. J., Zhang, Y. Y., Chen, Y. Z., and Wang, B. Y.: Characteristics of preferential flow paths and their impact on nitrate nitrogen transport on agricultural land, Polish Journal of Environmental Studies, 23, 1959-1964, <GotoISI>:/WOS:000347510700008, 2014.

Ciric, C., Ciffroy, P., and Charles, S.: Use of sensitivity analysis to identify influential and non-influential parameters within an aquatic ecosystem model, Ecological Modelling, 246, 119-130, https://doi.org/10.1016/j.ecolmodel.2012.06.024, <GotoISI>://WOS: $000310255100013,2012$.

Criss, R. E. and Winston, W. E.: Do nash values have value? Discussion and alternate proposals, Hydrological Processes, 22, 2723-2725, https://doi.org/10.1002/hyp.7072, <GotoISI>://WOS:000257954400029, 2008.

EEC: Council directive 91/676/eec of 12 december 1991 concerning the protection of waters against pollution caused by nitrates from agricultural sources oj $1375,1991$.

Ernstsen, V., Olsen, P., and Rosenbom, A. E.: Long-term monitoring of nitrate transport to drainage from three agricultural clayey till fields, Hydrology and Earth System Sciences, 19, 3475-3488, https://doi.org/10.5194/hess-19-3475-2015, <GotoISI>://WOS: $000360653600010,2015$.

Grundmann, G. L. and Rolston, D. E.: A water function approximation to degree of anaerobiosis associated with denitrification, Soil Science, 144, 437-441, https://doi.org/10.1097/00010694-198712000-00008, <GotoISI>://WOS:A1987L671100008, 1987.

Gupta, H. V., Kling, H., Yilmaz, K. K., and Martinez, G. F.: Decomposition of the mean squared error and nse performance criteria: Implications for improving hydrological modelling, Journal of Hydrology, 377, 80-91, https://doi.org/10.1016/j.jhydrol.2009.08.003, <GotoISI>://WOS:000271125800009, 2009.

Hansen, S.: Daisy, a flexible soil-plant-atmosphere system model, Report. Dept. Agric, 2002.

Hansen, S., Jensen, H., Nielsen, N., and Swenden, H.: Daisy: A soil plant system model. Danish simulation model for transformation and transport of energy and matter in the soil plant atmosphere system, The National Agency for Environmental Protection, p. 369 , 1990.

Hansen, S., Abrahamsen, P., and Petersen, C.: Daisy 2d simulation of silstrup and estrup, Report, University of Copenhagen, 2010a.

Hansen, S., Petersen, C., Abrahamsen, P., Nielsen, M., and Mollerup, M.: Daisy 2d simulation of rørrendegård, Technical report, University of Copenhagen, 2010b. 
Hansen, S., Abrahamsen, P., Petersen, C. T., and Styczen, M.: Daisy: Model use, calibration, and validation, Transactions of the Asabe, 55, 1315-1333,<GotoISI>://WOS:000309089900017, 2012a.

Hansen, S., Petersen, C., Mollerup, M., Abrahamsen, P., Gjettermann, B., Nielsen, M., Styczen, M., Poulsen, R., Lørup, J., Yamagata, K., and

Butts, M.: Flerdimensional modellering af vandstrømning og stoftransport i de $\varnothing$ verste $1-2 \mathrm{~m}$ af jorden i systemer med markdræn, Report, University of Copenhagen \& DHI, 2012b.

Hansson, B. G. and Hokfelt, B.: Long term treatment of moderate hypertension with penbutolol (hoe 893d). I. Effects on blood pressure, pulse rate, catecholamines in blood and urine, plasma renin activity and urinary aldosterone under basal conditions and following exercise, Eur J Clin Pharmacol, 9, 9-19, https://doi.org/10.1007/bf00613424, https://www.ncbi.nlm.nih.gov/pubmed/9298, 1975.

Heinen, M.: Simplified denitrification models: Overview and properties, Geoderma, 133, 444-463, https://doi.org/10.1016/j.geoderma.2005.06.010, <GotoISI>://WOS:000238981300024, 2006.

Hofstra, N. and Bouwman, A. F.: Denitrification in agricultural soils: Summarizing published data and estimating global annual rates, Nutrient Cycling in Agroecosystems, 72, 267-278, https://doi.org/10.1007/s10705-005-3109-y, <GotoISI>://WOS:000233044000006, 2005.

Hooghoudt, S. B.: Algemene beschouwing van het probleem van de detailontwatering en de infiltratie door middel van parallel loopende drains, greppels, slooten en kanalen, 1940.

Jabloun, M.: Cereal crop productivity and nitrogen cycling under climate change : Phd dissertation, Aarhus University, Department of Agroecology, Foulum, https://www.statsbiblioteket.dk/au/\#/search?query=recordID\%3A\%22sb_6242296\%22, 2015.

Jabloun, M., Li, X., Olesen, J. E., Schelde, K., and Tao, F.: Rdaisy: A comprehensive modelling framework for automated calibration, sensitivity and uncertainty analysis of the daisy model, Modelling Climate Change Impacts on Crop Production for Food Security, 2014.

Jain, A. K. and Dubes, R. C.: Algorithms for clustering data, vol. 6, Prentice hall Englewood Cliffs, 1988.

Jarvis, S. C., Stockdale, E. A., Shepherd, M. A., and Powlson, D. S.: Nitrogen mineralization in temperate agricultural soils: Processes and measurement, in: Advances in agronomy volume 57, edited by Sparks, D. L., vol. 57 of Advances in agronomy, pp. 187-235, Academic Press, https://doi.org/10.1016/s0065-2113(08)60925-6, http://www.sciencedirect.com/science/article/pii/S0065211308609256, 1996.

Klint, K. E. S. and Gravesen, P.: Fractures and biopores in weichselian clayey till aquitards at flakkebjerg, denmark, Hydrology Research, 30, 267-284, https://doi.org/10.2166/nh.1999.0015, http://dx.doi.org/10.2166/nh.1999.0015, 1999.

Knudsen, L., Østergaard, H., and E., S.: Kvælstof - et næringsstof og et miljøproblem, Report, Landskontoret for Planteavl, 2000.

515 Larsson, M. H. and Jarvis, N. J.: A dual-porosity model to quantify macropore flow effects on nitrate leaching, Journal of Environmental Quality, 28, 1298-1307, https://doi.org/10.2134/jeq1999.00472425002800040034x, <GotoISI>://WOS:000081345400032, 1999.

Lind, A. M.: Denitrification in the root zone, Tidsskrift for Planteavl, 84, 101-110, https://www.cabdirect.org/cabdirect/abstract/ 19801957950, 1980.

Lindhardt, B., Abildtrup, C., Vosgerau, H., Olsen, P., Torp, S., Iversen, B. V., Jørgensen, J. O., Plauborg, F., Rasmussen, P., and Gravesen, P.: The danish pesticide leaching assessment programme: Site characterization and monitoring design, Report, Geological Survey of Denmark and Greenland, 2001.

Manevski, K., Borgesen, C. D., Li, X., Andersen, M. N., Abrahamsen, P., Hu, C., and Hansen, S.: Integrated modelling of crop production and nitrate leaching with the daisy model, MethodsX, 3, 350-63, https://doi.org/10.1016/j.mex.2016.04.008, https://www.ncbi.nlm.nih. gov/pubmed/27222825, 2016. 41, 1355-1379, https://doi.org/10.1016/j.soilbio.2009.02.031, <GotoISI>://WOS:000267775300001, 2009. 
https://doi.org/10.5194/hess-2019-666

Preprint. Discussion started: 16 January 2020

(C) Author(s) 2020. CC BY 4.0 License.

(c) (i)

Mohanty, B. P., Bowman, R. S., Hendrickx, J. M. H., Simunek, J., and van Genuchten, M. T.: Preferential transport of nitrate to a tile drain in an intermittent-flood-irrigated field: Model development and experimental evaluation, Water Resources Research, 34, 1061-1076, https://doi.org/10.1029/98wr00294, <GotoISI>://WOS:000073407600011, 1998.

Mollerup, M.: Daisy 2d numerics, http://daisy.ku.dk/publications/Num2D-v2.pdf, 2010.

Morris, M. D.: Factorial sampling plans for preliminary computational experiments, Technometrics, 33, 161-174, https://doi.org/10.1080/00401706.1991.10484804, <GotoISI>://WOS:A1991FJ19800006, 1991.

Mualem, Y.: A new model for predicting the hydraulic conductivity of unsaturated porous media, Water resources research, 12, 513-522, 1976.

535 Muleta, M. K.: Model performance sensitivity to objective function during automated calibrations, Journal of hydrologic engineering, 17, 756-767, 2011.

Nagy, D., Rosenbom, A. E., Iversen, B. V., Jabloun, M., and Plauborg, F.: Estimating the degree of macropore flow to drainage at an agricultural clay till field for a 10-years period, Hydrology and Earth System Sciences, https://doi.org/10.5194/hess-2019-665, discussion paper, 2019.

540 Reddy, K. R. and Ronald, D. D.: Biogeochemistry of wetlands: Science and applications, vol. I, book section 8, CRC Press, 2008.

Richards, L. A.: Capillary conduction of liquids through porous mediums, Physics, 1, 318-333, https://doi.org/10.1063/1.1745010, <GotoISI>://WOS:000202861500042, 1931.

Rodrigo, A., Recous, S., Neel, C., and Mary, B.: Modelling temperature and moisture effects on c-n transformations in soils: Comparison of nine models, Ecological Modelling, 102, 325-339, https://doi.org/10.1016/s0304-3800(97)00067-7, http://www.sciencedirect.com/ science/article/pii/S0304380097000677, 1997

Rosenbom, A. E., Therrien, R., Refsgaard, J. C., Jensen, K. H., Ernstsen, V., and Klint, K. E.: Numerical analysis of water and solute transport in variably-saturated fractured clayey till, J Contam Hydrol, 104, 137-52, https://doi.org/10.1016/j.jconhyd.2008.09.001, https: //www.ncbi.nlm.nih.gov/pubmed/18926594, 2009.

Simunek, J., Jarvis, N. J., van Genuchten, M. T., and Gardenas, A.: Review and comparison of models for describing non-equilibrium and preferential flow and transport in the vadose zone, Journal of Hydrology, 272, 14-35, <GotoISI>://WOS:000181147900003, 2003.

Singh, J., Knapp, H. V., Arnold, J. G., and Demissie, M.: Hydrological modeling of the iroquois river watershed using hspf and swat, Journal of the American Water Resources Association, 41, 343-360, https://doi.org/10.1111/j.1752-1688.2005.tb03740.x, https://onlinelibrary. wiley.com/doi/abs/10.1111/j.1752-1688.2005.tb03740.x, 2005.

Van Genuchten, M. T.: A closed-form equation for predicting the hydraulic conductivity of unsaturated soils, Soil science society of America journal, 44, 892-898, 1980.

Vries, F. P. d.: Simulation of ecophysiological processes of growth in several annual crops, vol. 29, Int. Rice Res. Inst., 1989. 


\section{List of Figures}

1 Topography and field instrumentation of the Silstrup field $\ldots \ldots \ldots \ldots \ldots \ldots \ldots \ldots$

2 Crop rotations, a) Precipitation and cumulative drainage per season, b) Nitrate-N concentration in water abstracted from suction cups at $1 \mathrm{~m}$ depth and applications of mineral $\mathrm{N}$ fertilizer and injection of slurry (organic) c) Nitrate- $\mathrm{N}$ concentration in drainage water and cumulative flux of nitrate- $\mathrm{N}$ in drainage per season. . . . . . . 22

3 a) Schematic overview of the soil organic matter model included in the Daisy model. AOM = added organic matter, $\mathrm{SMB}=$ soil microbial biomass, and $\mathrm{SOM}=$ native soil organic matter; $\mathrm{fx}=$ partitioning coefficient. The inert SOM3 pool does not interact with the rest of the system. b) Schematic overview of the nitrogen model in Daisy (Hansen et al., 2012a)

4 a) Hydrological concept: DM - Drainage ended macropore, MM - Matrix ended macropore; b) Simulated accumulated drainage flow originating from the matrix and macropore domain with the corresponding nMAE, nRMSE[\%] and KGE for 2008-2009; c) Simulated accumulated $\mathrm{Br}^{-}$transport to drainage from matrix and macropore domain and measured $\mathrm{Br}^{-}$transport in the drain flow with the corresponding nMAE, nRMSE[\%] and KGE for 2000-2001. Subscripts: $D C$ - Cumulative Drainage [mm], $D D$ - Drainage Dynamics $\left[\mathrm{mm} \mathrm{h}^{-1}\right.$ ], BRDD - Br Drainage transport dynamics $\left[\mathrm{kg} \mathrm{Br}^{-} \mathrm{ha}^{-1} \mathrm{~h}^{-1}\right]$, BRDC - Cumulative $\mathrm{Br}^{-}$transport $\left[\mathrm{kg} \mathrm{Br}^{-} \mathrm{ha}^{-1}\right]$

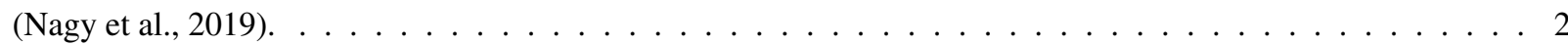

5 Sensitivity groups of selected $\mathrm{CP}$ and $\mathrm{SH}$ input parameters in regards to the 12 objective functions (Black Sensitive parameters, Gray - non-sensitive parameters) $\ldots \ldots \ldots \ldots \ldots \ldots$. . . . . . . . 25

Simulated accumulated $\mathrm{Br}^{-}$transport to drainage from matrix and macropore domain and measured $\mathrm{Br}^{-}$transport in the drain flow. Objectives $B R D 1$ and $B R C l$ with the corresponding nMAE, nRMSE[\%], and KGE for 2000-2001 before and after the calibration. In parenthesis, the performance for the objectives BRD2 and BRC2. 26

7 Simulated accumulated water transport from the matrix and macropore domain and measured drain flow. Objective $D D$ and $D C$ with the corresponding nMAE, nRMSE[\%] and KGE for 2000-2001, before and after the calibration.

8 Simulated seasonally accumulated $\mathrm{NO}_{3}-\mathrm{N}$ transport from matrix and macropore domain and accumulated measured $\mathrm{NO}_{3}-\mathrm{N}$ in the drainage. Included in the objectives $N D, \mathrm{NC}$ with the corresponding nMAE, nRMSE[\%] and KGE for calibration period of 2000-2007, before and after the calibration and additionally shown the seasonally accumulated denitrification from fast and slow pools. . . . . . . . . . . . . . . . 28

9 Default (Hansen, 2002) and old default (Hansen et al., 1990) water reduction factor of denitrification of DAISY and the calibrated water reduction factor of denitrification for the slow and fast pools. . . . . . . . . . . . . 29

10 Harvested DM and $\mathrm{N}$ of the storage organ before and after the calibration. For the objectives DM yield and $N$ yield, the performance measures nMAE, nRMSE[\%] and KGE . . . . . . . . . . . . . . . . 30 
https://doi.org/10.5194/hess-2019-666

Preprint. Discussion started: 16 January 2020

(c) Author(s) 2020. CC BY 4.0 License.

11 Simulated seasonally accumulated $\mathrm{NO}_{3}-\mathrm{N}$ transport from matrix and macropore domain and measured $\mathrm{NO}_{3}-\mathrm{N}$ in the drainage with the corresponding nMAE, nRMSE[\%], and KGE for the objectives $N D$ and $N C$ for the period of 2008-2009 before and after the calibration. Additionally, the seasonally accumulated denitrification

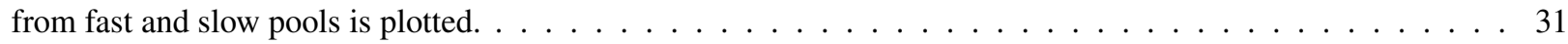

12 Simulated and measured soil $\mathrm{NO}_{3}-\mathrm{N}$ concentration $1 \mathrm{~m}$ depth from 2000 to 2010 a) before and $\mathbf{b}$ ) after the calibration. Performance measures calculated for the entire period for the simulated and measured $\mathrm{N}$ concen-

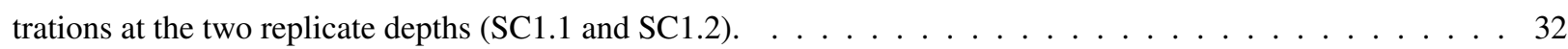

13 Simulated and measured soil $\mathrm{NO}_{3}$ - $\mathrm{N}$ concentration at $2 \mathrm{~m}$ depth from 2000 to 2010 before and after the calibration. Performance measures calculated for the entire period for the simulated and measured $\mathrm{N}$ concentrations

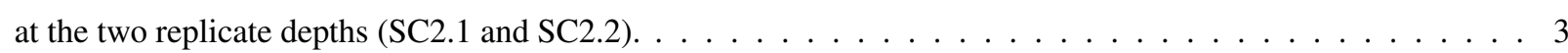




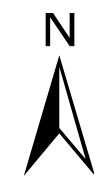

\section{Legend}
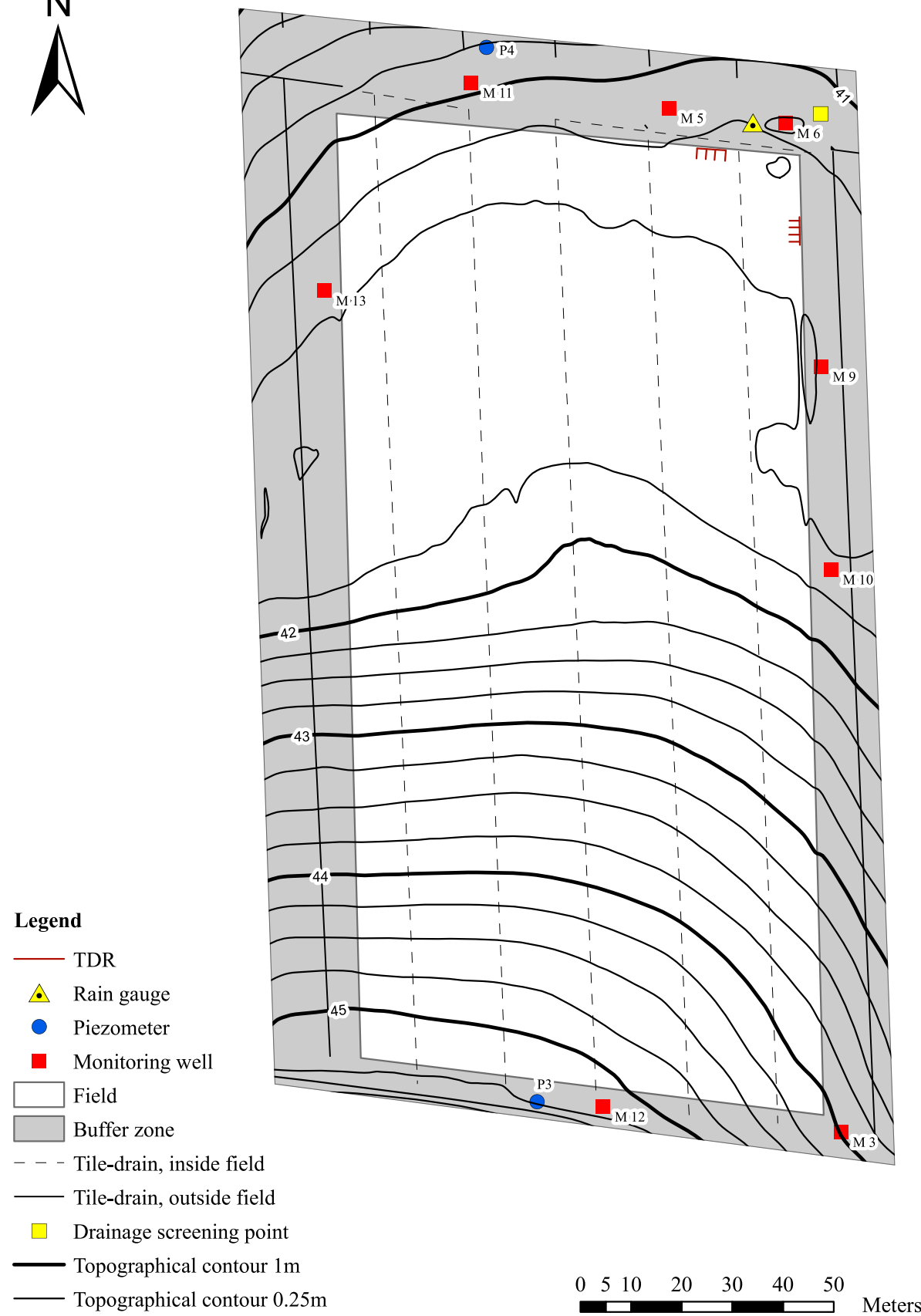

Figure 1. Topography and field instrumentation of the Silstrup field. 

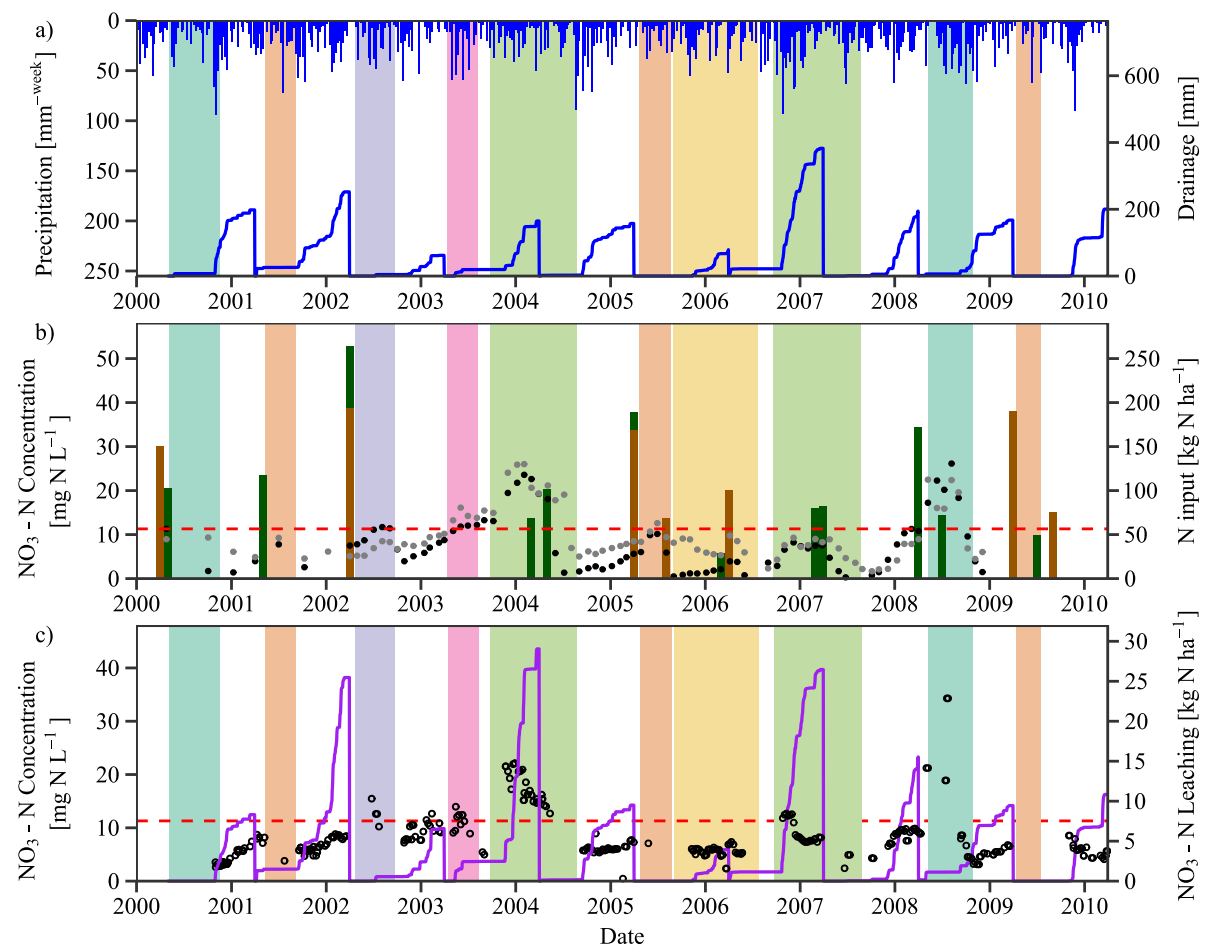

$\mathrm{NO}_{3}-\mathrm{N}$ concentration $\left[\mathrm{mg} \mathrm{N} \mathrm{L}^{-1}\right]$ : Fertilizer $\left[\mathrm{kg} \mathrm{N} \mathrm{ha}^{-1}\right]$ :

- Drainage

- Mineral N

- Matrix SC $1.1-1.00[\mathrm{~m}]$ b.g.s

Organic $\mathrm{N}$

Crop:

- Matrix SC $1.2-1.00[\mathrm{~m}]$ b.g.s

- - EU limit for drinking water

Water Transport [mm]:

$\mathrm{NO}_{3}$-N Flux [ $\mathrm{kg} \mathrm{N} \mathrm{ha}^{-1}$ :

arecipitation

Fodder Beet

- Cumulative Leaching _ Cumulative Drainage Winter Rape

- Cumulative Leaching _ Cumulative Drainage Winter Rape

Maize

Pea

Winter Wheat

Figure 2. Crop rotations, a) Precipitation and cumulative drainage per season, b) Nitrate-N concentration in water abstracted from suction cups at $1 \mathrm{~m}$ depth and applications of mineral $\mathrm{N}$ fertilizer and injection of slurry (organic) c) Nitrate- $\mathrm{N}$ concentration in drainage water and cumulative flux of nitrate- $\mathrm{N}$ in drainage per season. 
https://doi.org/10.5194/hess-2019-666

Preprint. Discussion started: 16 January 2020

(c) Author(s) 2020. CC BY 4.0 License.

a)

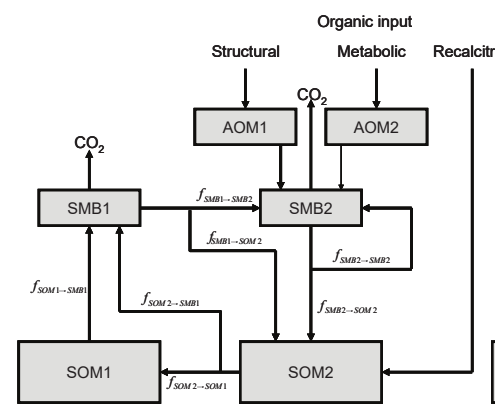

b)

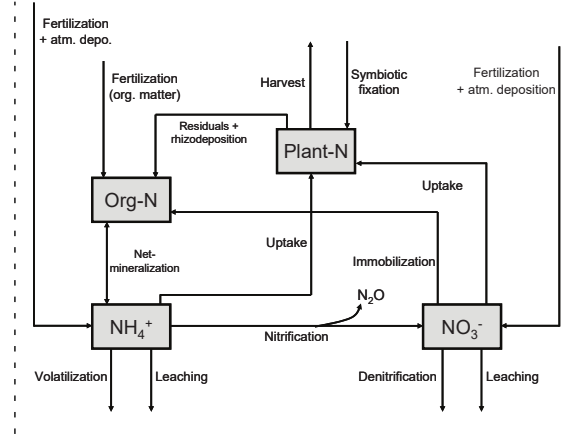

Figure 3. a) Schematic overview of the soil organic matter model included in the Daisy model. AOM = added organic matter, $\mathrm{SMB}=$ soil microbial biomass, and SOM = native soil organic matter; $f x=$ partitioning coefficient. The inert SOM3 pool does not interact with the rest of the system. b) Schematic overview of the nitrogen model in Daisy (Hansen et al., 2012a). 
https://doi.org/10.5194/hess-2019-666

Preprint. Discussion started: 16 January 2020

(c) Author(s) 2020. CC BY 4.0 License.

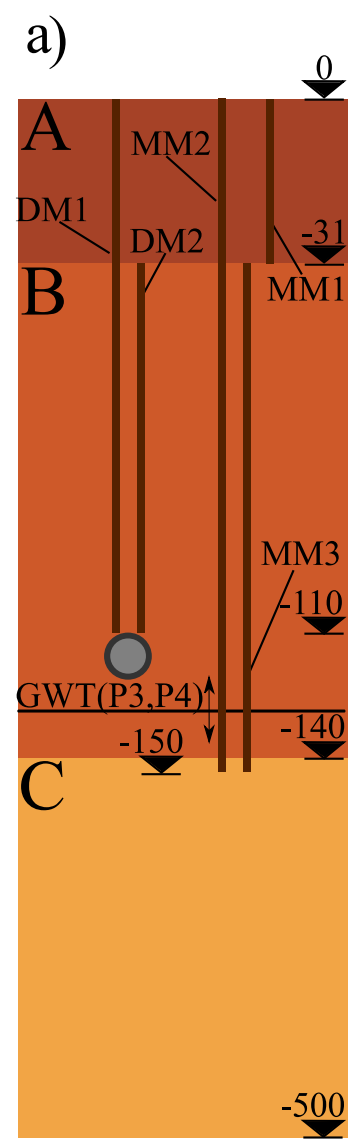

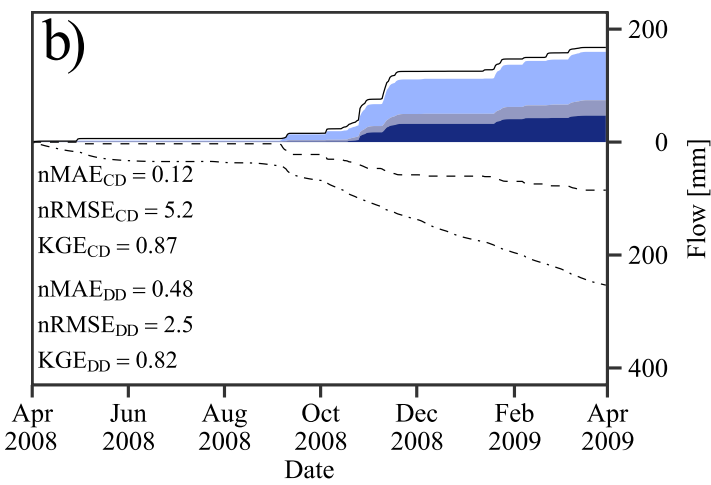

Macropore Flow - DM1 - -. - Matrix Deep Percolation

Macropore Flow - DM2 - - - Macropore Deep Percolation

Matrix Flow

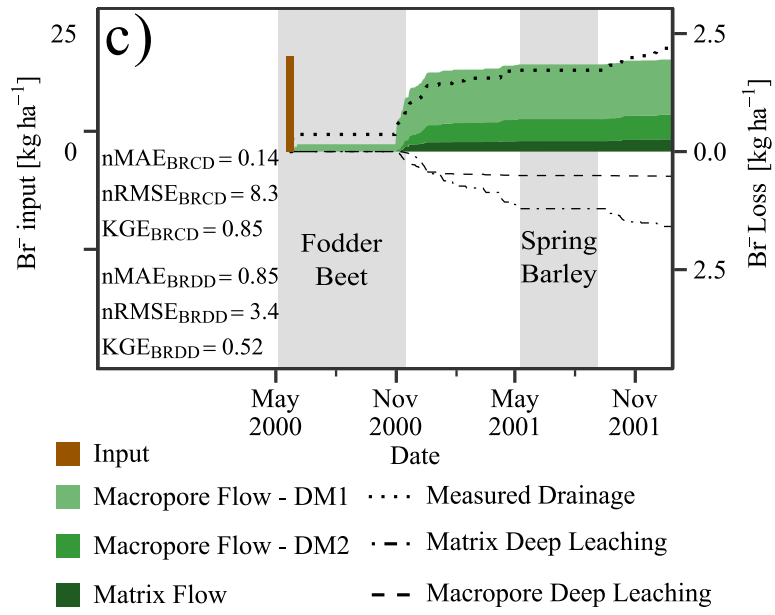

Figure 4. a) Hydrological concept: DM - Drainage ended macropore, MM - Matrix ended macropore; b) Simulated accumulated drainage flow originating from the matrix and macropore domain with the corresponding nMAE, nRMSE[\%] and KGE for 2008-2009; c) Simulated accumulated $\mathrm{Br}^{-}$transport to drainage from matrix and macropore domain and measured $\mathrm{Br}^{-}$transport in the drain flow with the corresponding nMAE, nRMSE[\%] and KGE for 2000-2001. Subscripts: $D C$ - Cumulative Drainage [mm], DD - Drainage Dynamics [mm h ${ }^{-1}$ ], BRDD Br Drainage transport dynamics $\left[\mathrm{kg} \mathrm{Br}^{-} \mathrm{ha}^{-1} \mathrm{~h}^{-1}\right]$, BRDC - Cumulative $\mathrm{Br}^{-}$transport $\left[\mathrm{kg} \mathrm{Br}^{-} \mathrm{ha}^{-1}\right]$ (Nagy et al., 2019). 
https://doi.org/10.5194/hess-2019-666

Preprint. Discussion started: 16 January 2020

(c) Author(s) 2020. CC BY 4.0 License.

Hydrology and o

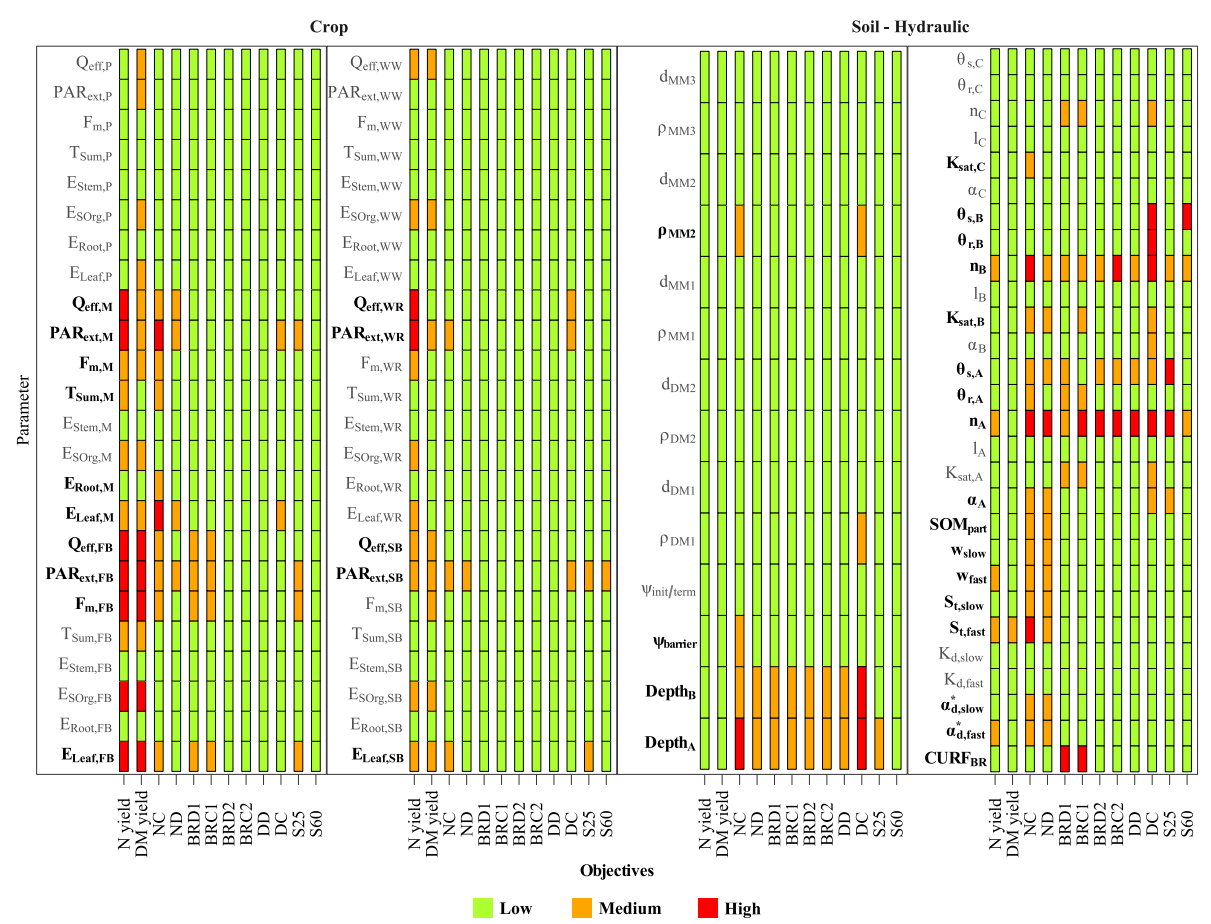

Figure 5. Sensitivity groups of selected $\mathrm{CP}$ and SH input parameters in regards to the 12 objective functions (Black - Sensitive parameters, Gray - non-sensitive parameters). 
https://doi.org/10.5194/hess-2019-666

Preprint. Discussion started: 16 January 2020

(c) Author(s) 2020. CC BY 4.0 License.

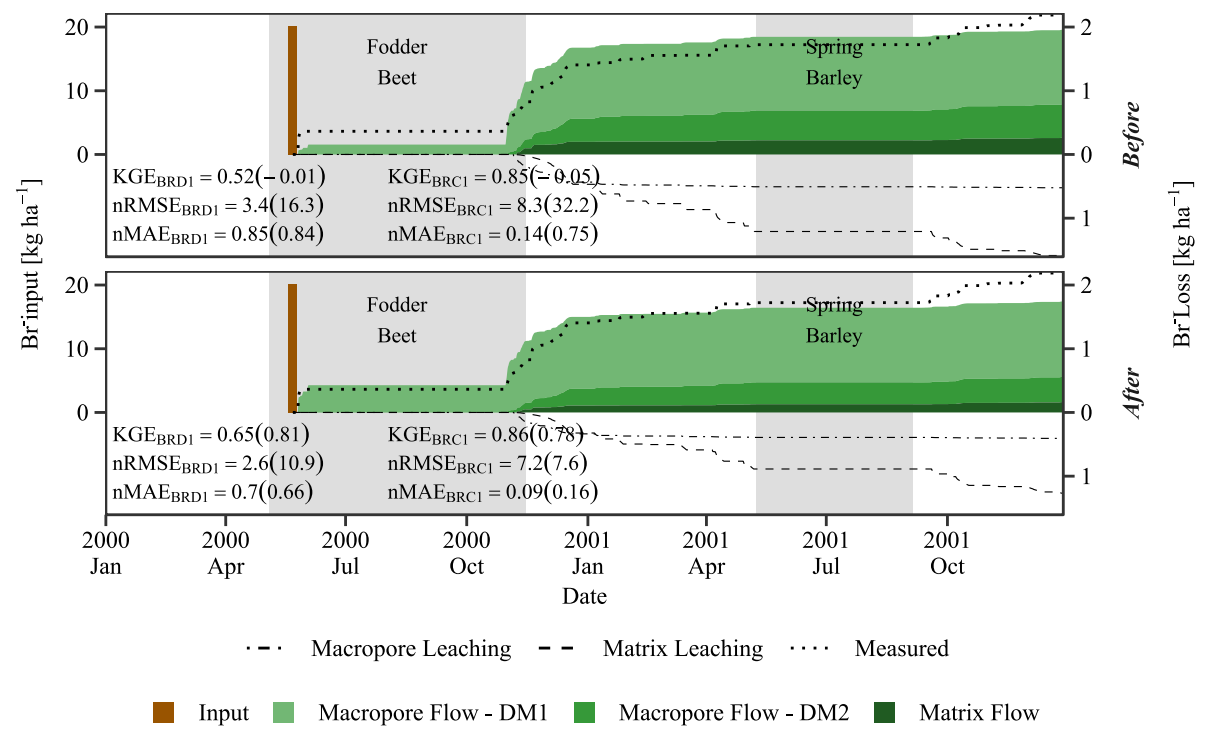

Figure 6. Simulated accumulated $\mathrm{Br}^{-}$transport to drainage from matrix and macropore domain and measured $\mathrm{Br}^{-}$transport in the drain flow. Objectives $B R D I$ and $B R C l$ with the corresponding nMAE, nRMSE[\%], and KGE for 2000-2001 before and after the calibration. In parenthesis, the performance for the objectives $B R D 2$ and $B R C 2$. 
https://doi.org/10.5194/hess-2019-666

Preprint. Discussion started: 16 January 2020

(c) Author(s) 2020. CC BY 4.0 License.

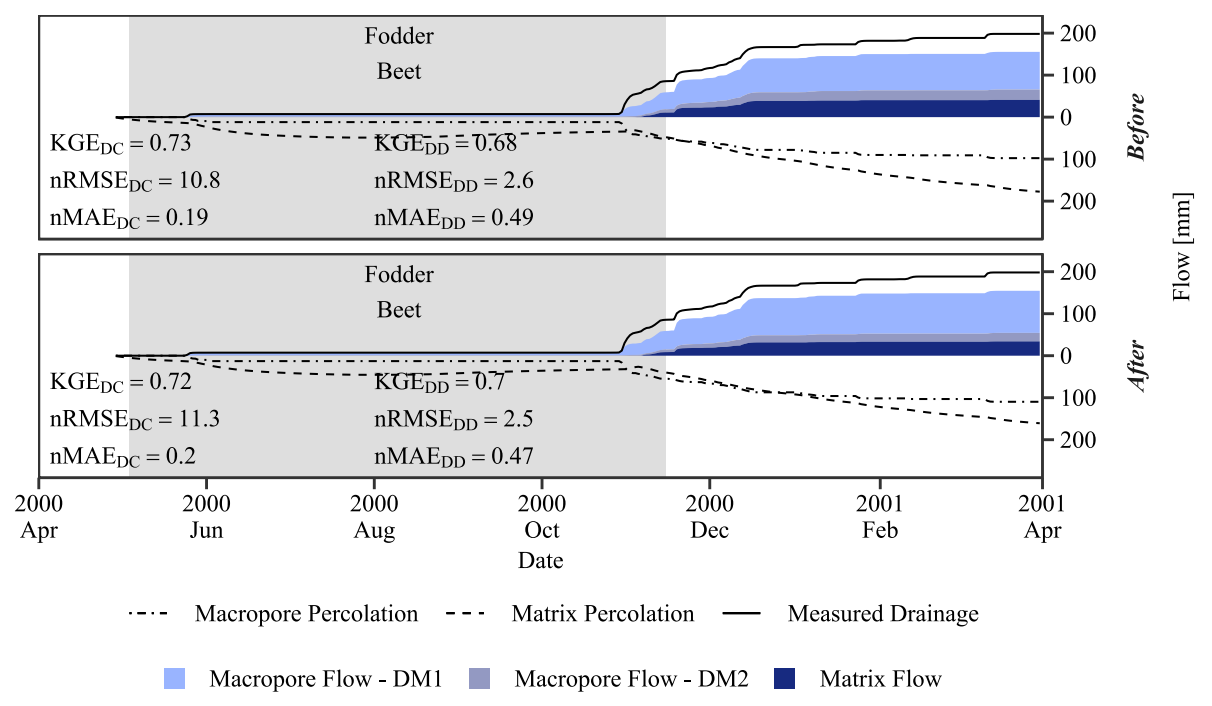

Figure 7. Simulated accumulated water transport from the matrix and macropore domain and measured drain flow. Objective $D D$ and $D C$ with the corresponding nMAE, nRMSE[\%] and KGE for 2000-2001, before and after the calibration. 
https://doi.org/10.5194/hess-2019-666

Preprint. Discussion started: 16 January 2020

(c) Author(s) 2020. CC BY 4.0 License.

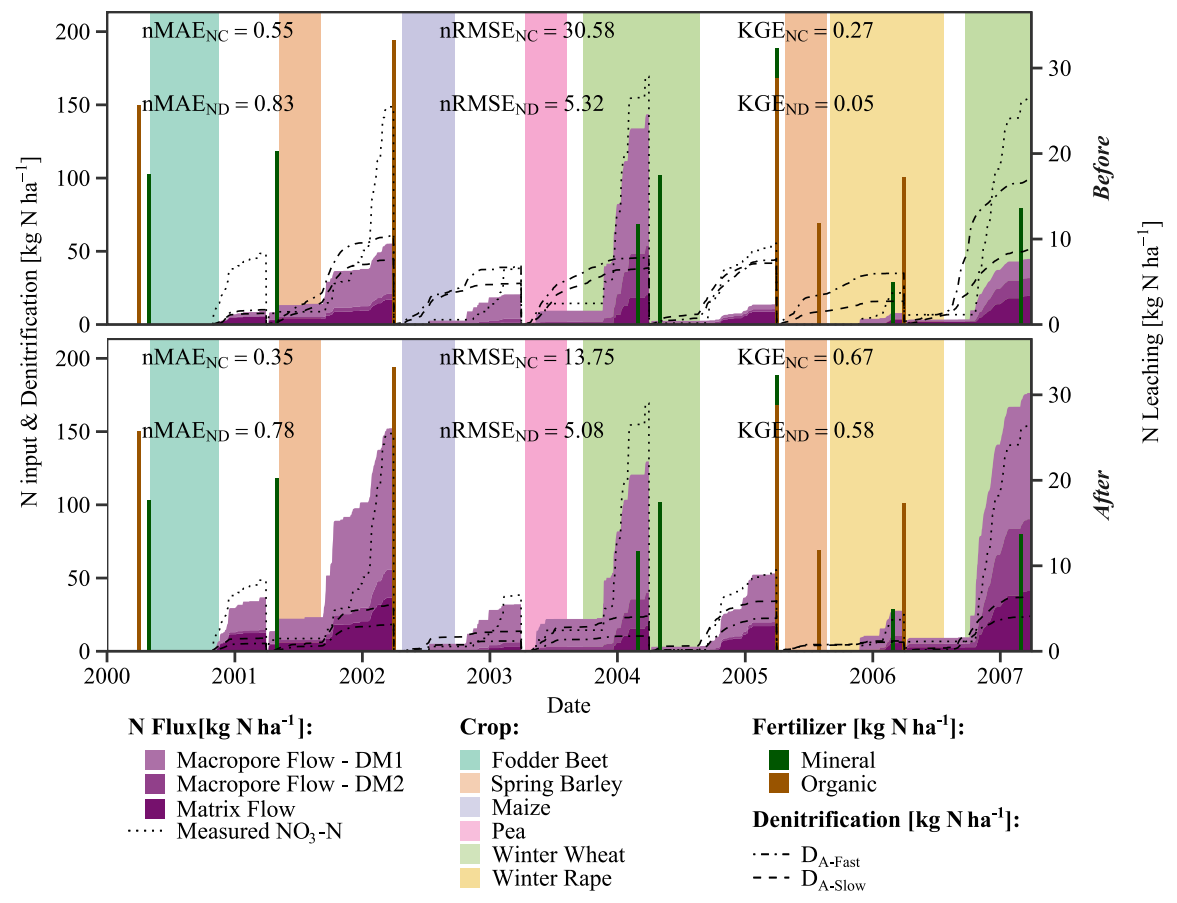

Figure 8. Simulated seasonally accumulated $\mathrm{NO}_{3}-\mathrm{N}$ transport from matrix and macropore domain and accumulated measured $\mathrm{NO}_{3}-\mathrm{N}$ in the drainage. Included in the objectives ND, NC with the corresponding nMAE, nRMSE[\%] and KGE for calibration period of 2000-2007, before and after the calibration and additionally shown the seasonally accumulated denitrification from fast and slow pools. 
https://doi.org/10.5194/hess-2019-666

Preprint. Discussion started: 16 January 2020

(c) Author(s) 2020. CC BY 4.0 License.

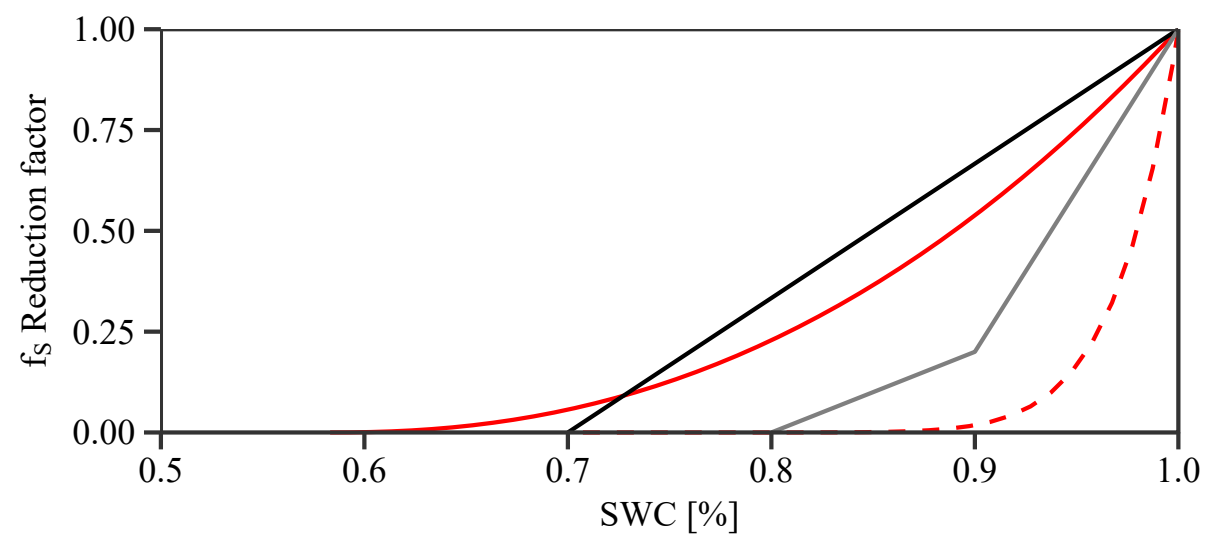

— DAISY Default — - Fast Pool

— DAISY Old Default — Slow Pool

Figure 9. Default (Hansen, 2002) and old default (Hansen et al., 1990) water reduction factor of denitrification of DAISY and the calibrated water reduction factor of denitrification for the slow and fast pools. 
https://doi.org/10.5194/hess-2019-666

Preprint. Discussion started: 16 January 2020

(c) Author(s) 2020. CC BY 4.0 License.

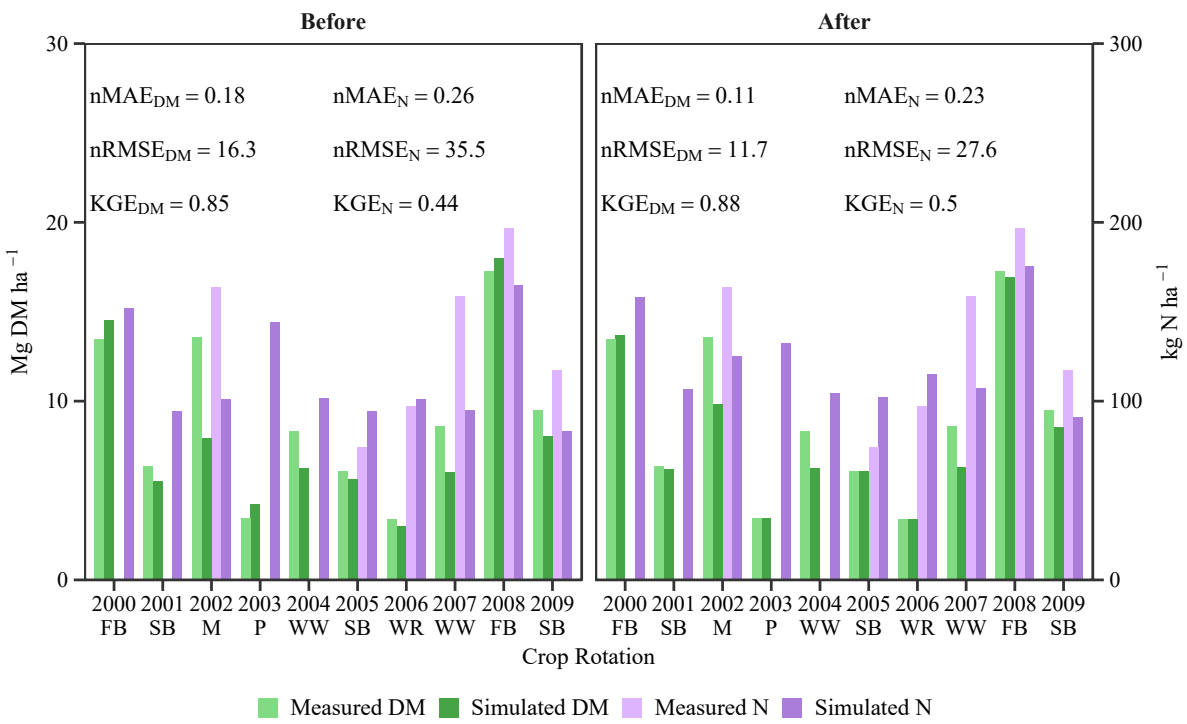

Figure 10. Harvested DM and $\mathrm{N}$ of the storage organ before and after the calibration. For the objectives DM yield and $N$ yield, the performance measures nMAE, nRMSE[\%] and KGE. 
https://doi.org/10.5194/hess-2019-666

Preprint. Discussion started: 16 January 2020

(c) Author(s) 2020. CC BY 4.0 License.

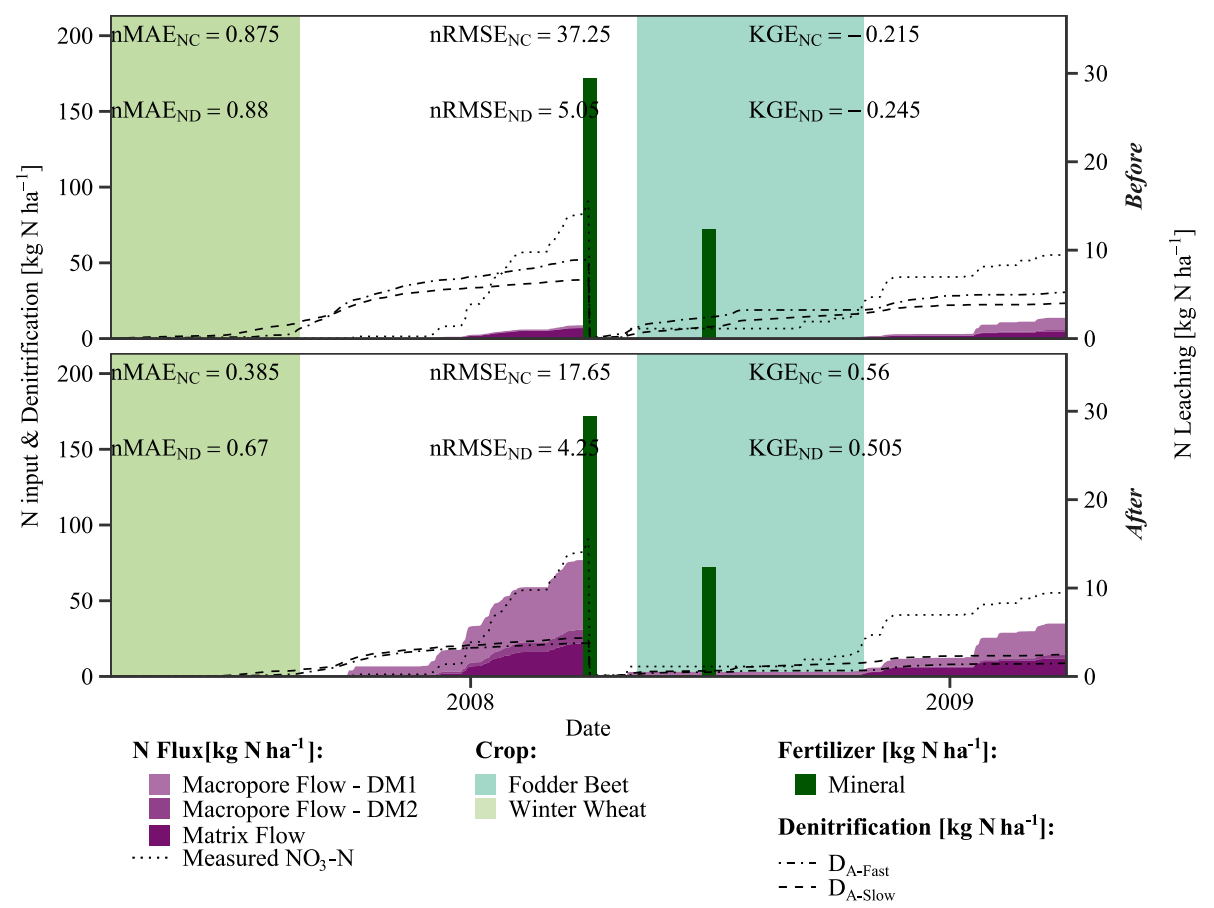

Figure 11. Simulated seasonally accumulated $\mathrm{NO}_{3}-\mathrm{N}$ transport from matrix and macropore domain and measured $\mathrm{NO}_{3}-\mathrm{N}$ in the drainage with the corresponding nMAE, nRMSE[\%], and KGE for the objectives $N D$ and $N C$ for the period of 2008-2009 before and after the calibration. Additionally, the seasonally accumulated denitrification from fast and slow pools is plotted. 


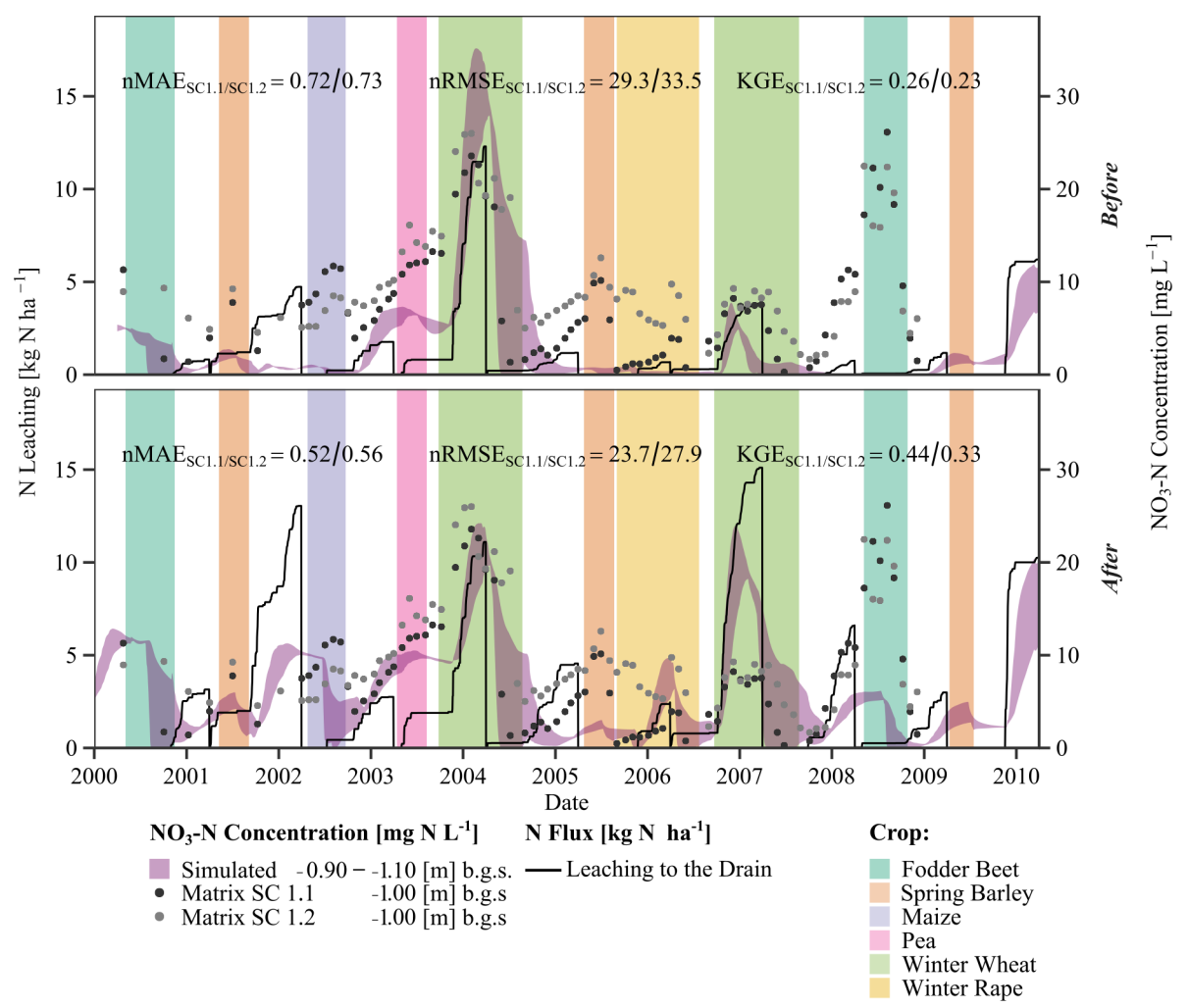

Figure 12. Simulated and measured soil $\mathrm{NO}_{3}-\mathrm{N}$ concentration $1 \mathrm{~m}$ depth from 2000 to 2010 a) before and b) after the calibration. Performance measures calculated for the entire period for the simulated and measured $\mathrm{N}$ concentrations at the two replicate depths (SC1.1 and SC1.2). 
https://doi.org/10.5194/hess-2019-666

Preprint. Discussion started: 16 January 2020

(c) Author(s) 2020. CC BY 4.0 License.

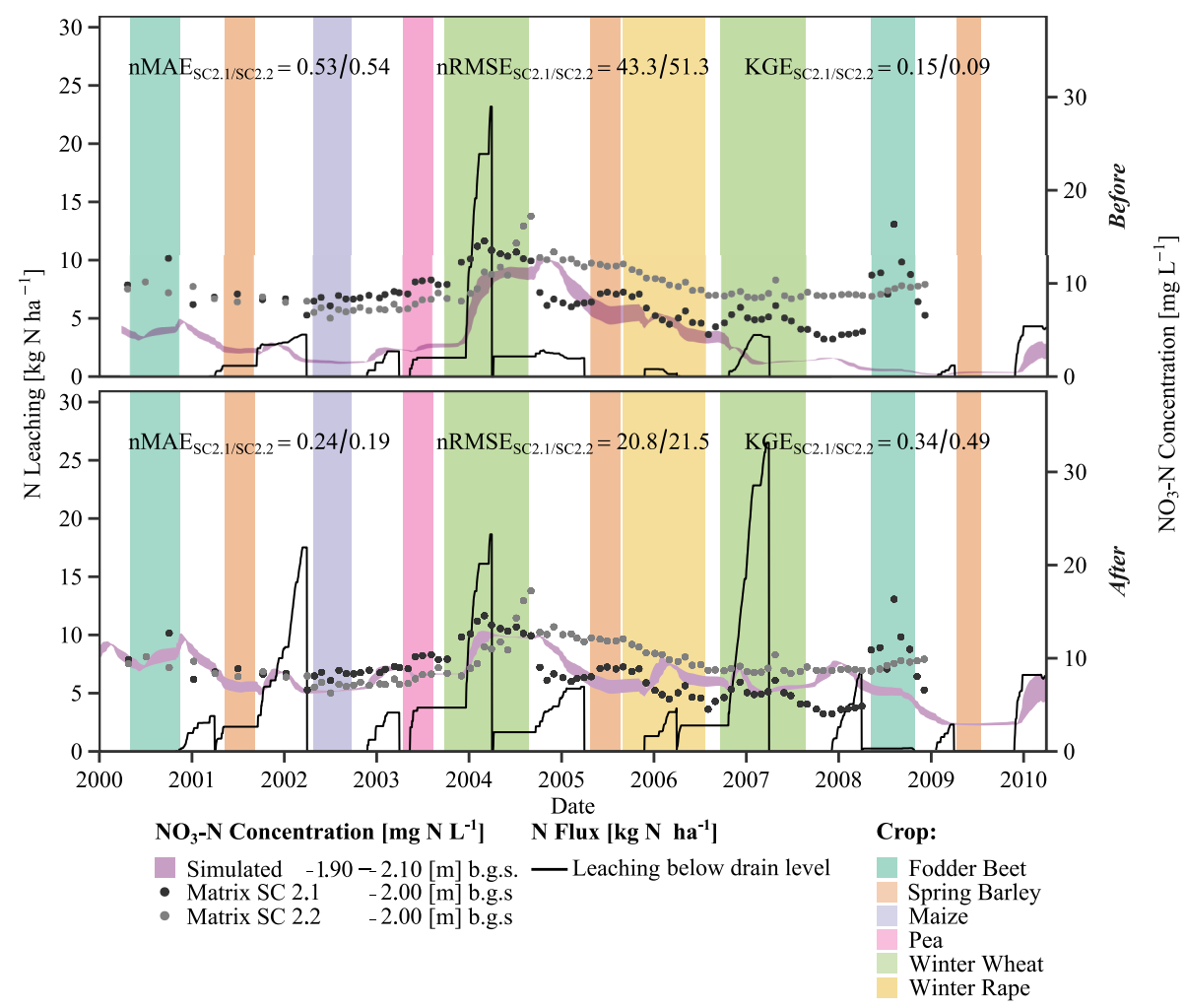

Figure 13. Simulated and measured soil $\mathrm{NO}_{3}-\mathrm{N}$ concentration at $2 \mathrm{~m}$ depth from 2000 to 2010 before and after the calibration. Performance measures calculated for the entire period for the simulated and measured N concentrations at the two replicate depths (SC2.1 and SC2.2). 


\section{List of Tables}

1 Initial van Genuchten - Mualem parameters for the matrix domain of A, B, and C (from Nagy et al. (2019)). $\theta_{r}$ is the residual water content, $\theta_{s}$ is the saturated water content, $\alpha$ and $n$ are the retention curve shape parameter, $K_{\text {sat }}$ saturated hydraulic conductivity, $l$ is the pore connectivity parameter in the Mualem equation. . . . . . 35

2 Initial parameters for the macropore domain of DM1, DM2 and MM1, MM2, MM3 (from (Nagy et al., 2019). Depth is the depth of the denoted horizon, $\psi_{\text {init/term }}$ is the initiating - terminating pressure of the macropore flow, $\psi_{\text {barrier }}$ is the required pressure difference between the macropore and matrix, $\rho$ is the density of the denoted macropore type, and $d$ is the diameter of the denoted macropore type . . . . . . . . . . . . . . 36

3 Initial parameters, taken from DAISY library (Hansen et al., 2012a) for crop models for the different crops in rotation (FB - Fodder Beet, M - Maize, P - Pea, SB - Spring Barley, WR - Winter Rape, WW - Winter Wheat). E parameters are conversion efficiency (growth respiration). $F_{m}$ is the maximum assimilation rate. $P A R_{e x t}$ is Photosynthetic Active Radiation extinction coefficient. $Q_{\text {eff }}$ quantum efficiency at low light. $T_{\text {sum }}$ is the temperature sum at emergence of the crop. . . . . . . . . . . . . . . . . . . . . . . . 37

4 Initial parameters for denitrification, $\mathrm{Br}^{-}$uptake, and $\mathrm{SOM} \ldots \ldots \ldots \ldots \ldots \ldots$

5 Calibrated objectives and the normalized standard deviation of the measurements for the calibration period of 2000-2007. Initial objective values shown in brackets. nMAE - normalized mean absolute error, $\mathrm{nSD}_{\text {mean }}-\mathrm{SD}$ normalized by mean observation, nRMSE[\%] - normalized root mean squared error, nSD[\%] - SD normalized by the maximum deviation of the observation, KGE - Kling-Gupta Efficiency. . . . . . . . . . . . . . . . . 39 
https://doi.org/10.5194/hess-2019-666

Preprint. Discussion started: 16 January 2020

(C) Author(s) 2020. CC BY 4.0 License.

Table 1. Initial van Genuchten - Mualem parameters for the matrix domain of A, B, and C (from Nagy et al. (2019)). $\theta_{r}$ is the residual water content, $\theta_{s}$ is the saturated water content, $\alpha$ and $n$ are the retention curve shape parameter, $K_{\text {sat }}$ saturated hydraulic conductivity, $l$ is the pore connectivity parameter in the Mualem equation.

\begin{tabular}{|c|c|c|c|c|c|c|c|c|}
\hline $\begin{array}{c}\theta_{r, A} \\
\mathrm{~cm}^{3} \mathrm{~cm}^{-3}\end{array}$ & $\begin{array}{c}\theta_{r, B} \\
\mathrm{~cm}^{3} \mathrm{~cm}^{-3}\end{array}$ & $\begin{array}{c}\theta_{r, C} \\
\mathrm{~cm}^{3} \mathrm{~cm}^{-3}\end{array}$ & $\begin{array}{c}\theta_{s, A} \\
\mathrm{~cm}^{3} \mathrm{~cm}^{-3}\end{array}$ & $\begin{array}{c}\theta_{s, B} \\
\mathrm{~cm}^{3} \mathrm{~cm}^{-3}\end{array}$ & $\begin{array}{c}\theta_{s, C} \\
\mathrm{~cm}^{3} \mathrm{~cm}^{-3}\end{array}$ & $\begin{array}{c}l_{A} \\
-\end{array}$ & $\begin{array}{l}l_{B} \\
-\end{array}$ & $\begin{array}{l}l_{C} \\
-\end{array}$ \\
\hline 0.01 & 0.013 & 0.01 & 0.4063 & 0.3783 & 0.2938 & 0.5 & 0.5 & 0.5 \\
\hline$K_{\text {sat }, A}$ & $K_{\text {sat }, B}$ & $K_{\text {sat }, C}$ & $\alpha_{A}$ & $\alpha_{B}$ & $\alpha_{C}$ & $n_{A}$ & $n_{B}$ & $n_{C}$ \\
\hline $\mathrm{cm} \mathrm{h}^{-1}$ & $\mathrm{~cm} \mathrm{~h}^{-1}$ & $\mathrm{~cm} \mathrm{~h}^{-1}$ & - & - & - & - & $\begin{array}{lll}- & -\end{array}$ & $\begin{array}{ll}- \\
-\end{array}$ \\
\hline 10.71 & 0.03 & 0.28 & 0.051 & 0.0045 & 0.001 & 1.186 & 1.2005 & 1.2154 \\
\hline
\end{tabular}


https://doi.org/10.5194/hess-2019-666

Preprint. Discussion started: 16 January 2020

(C) Author(s) 2020. CC BY 4.0 License.

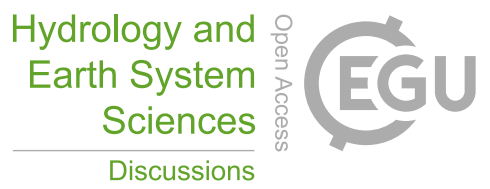

Table 2. Initial parameters for the macropore domain of DM1, DM2 and MM1, MM2, MM3 (from (Nagy et al., 2019). Depth is the depth of the denoted horizon, $\psi_{\text {init } / t e r m}$ is the initiating - terminating pressure of the macropore flow, $\psi_{\text {barrier }}$ is the required pressure difference between the macropore and matrix, $\rho$ is the density of the denoted macropore type, and $d$ is the diameter of the denoted macropore type.

\begin{tabular}{|c|c|c|c|c|c|c|c|}
\hline $\begin{array}{c}\operatorname{Depth}_{A} \\
\mathrm{~cm}\end{array}$ & $\begin{array}{c}\text { Depth }_{B} \\
\mathrm{~cm}\end{array}$ & $\begin{array}{c}\psi_{\text {init } / \text { term }} \\
\mathrm{cm}\end{array}$ & $\begin{array}{c}\psi_{\text {barrier }} \\
\mathrm{cm}\end{array}$ & $\begin{array}{c}\rho_{D M 1} \\
\mathrm{~m}^{-2} \\
\end{array}$ & $\begin{array}{c}\rho_{D M 2} \\
\mathrm{~m}^{-2} \\
\end{array}$ & $\begin{array}{c}d_{D M 1} \\
\mathrm{~mm}\end{array}$ & $\begin{array}{c}d_{D M 2} \\
\mathrm{~mm}\end{array}$ \\
\hline \multirow[t]{3}{*}{-39.29} & -140 & -2.93 & -5 & 5.489 & 12.643 & 3 & 3 \\
\hline & $\begin{array}{l}\rho_{\mathrm{mm} 1} \\
\mathrm{~m}^{-2}\end{array}$ & $\begin{array}{c}\rho_{\mathrm{mm} 2} \\
\mathrm{~m}^{-2}\end{array}$ & $\begin{array}{c}\rho_{\mathrm{mm} 3} \\
\mathrm{~m}^{-2}\end{array}$ & $\begin{array}{c}d_{\mathrm{mm} 1} \\
\mathrm{~mm}\end{array}$ & $\begin{array}{c}d_{\mathrm{mm} 2} \\
\mathrm{~mm}\end{array}$ & $\begin{array}{c}d_{\mathrm{mm} 3} \\
\mathrm{~mm}\end{array}$ & \\
\hline & 100 & 11.5 & 11.5 & 2 & 3 & 3 & \\
\hline
\end{tabular}


https://doi.org/10.5194/hess-2019-666

Preprint. Discussion started: 16 January 2020

(c) Author(s) 2020. CC BY 4.0 License.

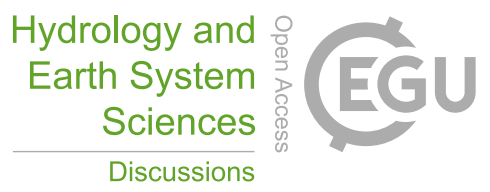

Table 3. Initial parameters, taken from DAISY library (Hansen et al., 2012a) for crop models for the different crops in rotation (FB Fodder Beet, M - Maize, P - Pea, SB - Spring Barley, WR - Winter Rape, WW - Winter Wheat). E parameters are conversion efficiency (growth respiration). $F_{m}$ is the maximum assimilation rate. $P A R_{e x t}$ is Photosynthetic Active Radiation extinction coefficient. $Q_{e f f}$ quantum efficiency at low light. $T_{\text {sum }}$ is the temperature sum at emergence of the crop.

\begin{tabular}{c|cccccc} 
Parameter & $\mathbf{F B}$ & $\mathbf{M}$ & $\mathbf{P}$ & $\mathbf{S B}$ & $\mathbf{W R}$ & $\mathbf{W W}$ \\
\hline$E_{\text {Root }}$ & 0.69 & 0.78 & 0.69 & 0.69 & 0.69 & 0.69 \\
$E_{\text {Stem }}$ & 0.66 & 0.69 & 0.66 & 0.66 & 0.66 & 0.66 \\
$E_{\text {Leaf }}$ & 0.66 & 0.75 & 0.7 & 0.68 & 0.68 & 0.68 \\
$E_{\text {SOrg }}$ & 0.7 & 0.8 & 0.55 & 0.7 & 0.5 & 0.7 \\
$T_{\text {sum }}$ & 250 & 180 & 100 & 100 & 180 & 100 \\
$F_{m}$ & 4 & 6.5 & 4 & 5 & 5.25 & 5.59 \\
$P A R_{\text {ext }}$ & 0.67 & 0.8 & 0.3 & 0.6 & 0.7 & 0.6 \\
$Q_{\text {eff }}$ & 0.06 & 0.04 & 0.04 & 0.04 & 0.05 & 0.05
\end{tabular}


https://doi.org/10.5194/hess-2019-666

Preprint. Discussion started: 16 January 2020

(C) Author(s) 2020. CC BY 4.0 License.

Table 4. Initial parameters for denitrification, $\mathrm{Br}^{-}$uptake, and SOM.

\begin{tabular}{cccccc}
$C U R F_{B R}$ & $\alpha_{d}^{*}$ & $K_{d}$ & $S O M_{\text {ratio }}$ & $S_{t}$ & $w$ \\
- & $\left(\mathrm{g} \mathrm{NO}_{3}-\mathrm{N} \mathrm{h}^{-1}\right)\left(\mathrm{g} \mathrm{CO}_{2}-\mathrm{C} \mathrm{h}^{-1}\right)^{-1}$ & - & - & - & - \\
\hline 0.2 & 0.1 & 0.020833 & 1 & 0.7 & 1
\end{tabular}


https://doi.org/10.5194/hess-2019-666

Preprint. Discussion started: 16 January 2020

(c) Author(s) 2020. CC BY 4.0 License.

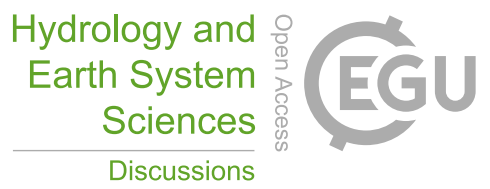

Table 5. Calibrated objectives and the normalized standard deviation of the measurements for the calibration period of 2000-2007. Initial objective values shown in brackets. $\mathrm{nMAE}$ - normalized mean absolute error, $\mathrm{nSD}_{\text {mean }}-\mathrm{SD}$ normalized by mean observation, $\mathrm{nRMSE} \%$ ] normalized root mean squared error, nSD[\%] - SD normalized by the maximum deviation of the observation, KGE - Kling-Gupta Efficiency.

\begin{tabular}{l|rll|rlr|rr|} 
Objectives & \multicolumn{2}{|c}{ nMAE } & nSD $_{\text {mean }}$ & \multicolumn{2}{|c|}{ nRMSE[\%] } & nSD[\%] & \multicolumn{2}{|c}{ KGE } \\
\hline N yield & 0.23 & $(0.26)$ & 0.37 & 27.6 & $(35.5)$ & 41.4 & 0.5 & $(0.44)$ \\
DM yield & 0.11 & $(0.18)$ & 0.54 & 11.7 & $(16.3)$ & 34.9 & 0.88 & $(0.85)$ \\
ND & 0.7 & $(0.81)$ & 3.49 & 4.3 & $(4.66)$ & 5.22 & 0.56 & $(-0.03)$ \\
NC & 0.31 & $(0.67)$ & 1.18 & 13.96 & $(31.64)$ & 34.5 & 0.68 & $(0.08)$ \\
BRD1 & 0.7 & $(0.87)$ & 4.28 & 2.6 & $(3.3)$ & 3.8 & 0.65 & $(0.61)$ \\
BRC1 & 0.09 & $(0.2)$ & 0.55 & 7.2 & $(12.4)$ & 30.6 & 0.86 & $(0.73)$ \\
BRD2 & 0.66 & $(0.74)$ & 2.5 & 10.9 & $(13.9)$ & 19.5 & 0.81 & $(0.16)$ \\
BRC2 & 0.16 & $(0.65)$ & 1.97 & 7.6 & $(27.9)$ & 38.5 & 0.78 & $(0.09)$ \\
DD & 0.53 & $(0.52)$ & 3.5 & 2.6 & $(2.66)$ & 4.44 & 0.74 & $(0.72)$ \\
DC & 0.13 & $(0.12)$ & 1.17 & 5.4 & $(5.22)$ & 34.82 & 0.89 & $(0.89)$ \\
S25 & 0.12 & $(0.1)$ & 0.18 & 19.36 & $(17.04)$ & 25.24 & 0.64 & $(0.71)$ \\
S60 & 0.04 & $(0.05)$ & 0.04 & 29.4 & $(35.26)$ & 20.78 & 0.09 & $(0.03)$ \\
MEAN & 0.315 & $(0.43)$ & 1.65 & 11.89 & $(17.15)$ & 24.48 & 0.67 & $(0.44)$
\end{tabular}


https://doi.org/10.5194/hess-2019-666

Preprint. Discussion started: 16 January 2020

(c) Author(s) 2020. CC BY 4.0 License.

Table 6. Calibrated SH/CP parameters. Initial parameter values shown in brackets.

\begin{tabular}{|c|c|c|c|c|c|c|}
\hline$\theta_{r, A}$ & $\theta_{r, B}$ & $\theta_{s, A}$ & $\theta_{s, B}$ & $\alpha_{A}$ & $n_{A}$ & $n_{B}$ \\
\hline 0.01 & 0.013 & 0.39 & 0.39 & 0.053 & 1.231 & 1.176 \\
\hline$(0.01)$ & $(0.013)$ & $(0.41)$ & $(0.38)$ & $(0.051)$ & (1.186) & (1.201) \\
\hline$K_{\text {sat, } B}$ & $K_{s a t, C}$ & $\psi_{\text {barrier }}$ & $\rho_{M M 3}$ & $S O M_{\text {ratio }}$ & $\operatorname{Depth}_{A}$ & Depth $_{B}$ \\
\hline 0.029 & 0.285 & -5.15 & 11.72 & 1.67 & -35.4 & -141.4 \\
\hline$(0.03)$ & $(0.28)$ & $(-5)$ & (11.5) & (1) & $(-39.3)$ & $(-140)$ \\
\hline$\alpha_{d, f a s t}^{*}$ & $\alpha_{d, \text { slow }}^{*}$ & $S_{t, \text { fast }}$ & $w_{\text {fast }}$ & $S_{t, \text { slow }}$ & $w_{\text {slow }}$ & \\
\hline 0.071 & 0.154 & 0.71 & 9.6 & 0.58 & 2.3 & \\
\hline$(0.1)$ & (0.1) & (0.7) & (1) & (0.7) & (1) & \\
\hline$E_{\text {Leaf, } F B}$ & $E_{S O r g, F B}$ & $F_{m, F B}$ & $P A R_{e x t, F B}$ & $Q_{e f f, F B}$ & $E_{\text {Leaf }, S B}$ & $P A R_{e x t, S B}$ \\
\hline 0.76 & 0.62 & 4.61 & 0.58 & 0.07 & 0.79 & 0.52 \\
\hline$(0.66)$ & $(0.7)$ & $(4.00)$ & $(0.67)$ & $(0.06)$ & $(0.68)$ & $(0.60)$ \\
\hline$Q_{e f f, S B}$ & $E_{\text {Leaf }, M}$ & $E_{\text {Root }, M}$ & $T_{\text {sum, } M}$ & $F_{m, M}$ & $P A R_{e x t, M}$ & $Q_{e f f, M}$ \\
\hline 0.05 & 0.86 & 0.69 & 156.75 & 7.57 & 0.76 & 0.05 \\
\hline$(0.04)$ & $(0.75)$ & $(0.78)$ & (180) & $(6.50)$ & $(0.80)$ & $(0.04)$ \\
\hline$P A R_{e x t, W R}$ & $Q_{e f f, W R}$ & $C U R F_{B R}$ & & & & \\
\hline 0.57 & 0.06 & 0.0034 & & & & \\
\hline$(0.70)$ & $(0.05)$ & $(0.0)$ & & & & \\
\hline
\end{tabular}

